\title{
Chapter 6 \\ Community Resettlement in Louisiana: \\ Learning from Histories of Horror and Hope
}

Nathan Jessee

\subsection{Introduction}

It was a warm evening in early May of 2016. I made my way up two flights of stairs to Victor's wooden wraparound porch. His family's house is a comfortable prefab that looms 12 feet above the banks of Bayou Pointe-au-Chien on the border of Lafourche and Terrebonne parishes in Southeast Louisiana. It was built in 2008 after Hurricane Gustav blew the roof off their previous one-which itself had sustained extensive flood damage and needed to be raised after Hurricane Lili in 2002. I met Victor a little over a year earlier when he participated in a series of film screenings and panel discussions I co-organized in the Northeast United States. The events were coordinated to raise awareness about the recurrent disasters affecting his tribe, the Isle de Jean Charles Biloxi-Chitimacha-Choctaw Indians of Louisiana (IDJC), and their plans for the future. Victor and the rest of the IDJC Tribe trace their heritage to Choctaw, Biloxi, and Chitimacha ancestors who, by the early 1840s, had escaped Indian Removal-era violence and resettled on a ridge of land 90 miles southwest of New Orleans called the Isle de Jean Charles, referred to locally as "the Island."

\footnotetext{
"This is not the first time we have had to resettle. Our ancestors were displaced by treaties and Indian Removal. My papa's generation was displaced from the Island. We're already a displaced Tribe. That's why we've got to get it right."

Tribal member, Isle de Jean Charles Biloxi-Chitimacha-Choctaw Tribe

"The question of migration and climate change is not a contingent problem to be solved (or that can be solved) by some technocratic protocol—but rather a metaphor carving out space to pose, contest and struggle for the highly political questions about the climate, mobility, economy, and the society we want."

Giovanni Bettini (2017, p. 90)
}

N. Jessee $(\square)$

Department of Anthropology, Temple University, Philadelphia, PA, USA

e-mail: nathan.jessee@temple.edu

S. Laska (ed.), Louisiana's Response to Extreme Weather,

Extreme Weather and Society, https://doi.org/10.1007/978-3-030-27205-0_6 
For generations, the people of Isle de Jean Charles fished, hunted, trapped, tended to livestock, and grew their food. Today, adults longingly remember shrimping and crabbing with their families in the bayou that ran the length of the Island-a sanctuary in an area once considered "uninhabitable swampland" by government officials. The Isle de Jean Charles Biloxi-Chitimacha-Choctaw Indians are one of the many indigenous nations who inhabit the land currently occupied by the state of Louisiana. They are one of 15 tribes recognized by the state government, and though they have yet to be formally recognized by the US Bureau of Indian Affairs, the Isle de Jean Charles Biloxi-Chitimacha-Choctaw Tribe has participated in programs administered by multiple federal agencies including the Environmental Protection Agency, Department of Agriculture's Natural Resources Conservation Service, and Department of Housing and Urban Development. As someone who was raised and lived as a young adult on the Island, Victor maintains intimate knowledge of how life and landscape have changed there. And after having moved about 6 miles "up the bayou" to nearby Pointe-aux-Chenes in large part due to the recurrent flooding of the one road that connects the Island to the rest of Louisiana, he knows what it means to leave as a result of changing environmental conditions. Additionally, as the son of a former Chief and someone who has been active within their tribal-driven plans to resettle inland, Victor is able to speak to the long history of organizing to bring resources and support to the Island Tribe.

Upon entering his house, I was greeted by a number of familiar faces sitting around the supper table for an informal meeting: Victor and his family, Tribal Chief Albert Naquin, two teenagers who have represented the Tribe at a number of conferences and in media coverage of land loss, and their father. Also sitting at the table were Dr. Shirley Laska and Dr. Kristina Peterson, co-founders of the Lowlander Center-a nonprofit advocacy and education center who in 2010 established a partnership with the Isle de Jean Charles Biloxi-Chitimacha-Choctaw Tribal Council to support their plans to reunite their displaced people and rejuvenate their traditional ways of life together on higher ground. The Tribal leadership and Lowlander Center were finalizing plans for an upcoming trip to Washington D.C. where Chief Naquin was invited to share his experiences of coastal land loss and resettlement planning as part of a congressional forum entitled "Confronting a Rising Tide: The Climate Refugee Crisis." At first the conversation was mostly light-hearted and speckled with jokes and laughter, meandering from the teenagers' college plans to food and family updates. As the discussion began to focus on the upcoming trip, the tribal members in attendance began to discuss their uncertainty as to the future of the resettlement, despite securing recent financial support through the state of Louisiana's application to the National Disaster Resilience Competition (NDRC).

"It's hard to know what to say to people, because we don't hear anything," Chief Albert explained. "We haven't really heard what the state wants to do since they got the money over three months ago. We don't know what's going to happen. Maybe they want to make our tribal resettlement into just another subdivision? We don't know." Responding to the concern, Dr. Laska asked, "What do you think is most important for you to convey on the climate migration panel?" Chief Albert reflected, "You know, treaties are made to be broken," he said with a pause. "Well, they aren't 
supposed to be broken, but they always are. This is going to be the same old forced relocation again. The white people pushed the Indians out. We came down here, and some would say we were cowards. Others would say we were smart. Then they had white people drilling up the oil and so now they're pushing us back. We hope this is not another treaty made, another treaty broken." Everyone listened intently, and after a moment, Victor responded. "Let's tell them." He went on to suggest that on the upcoming panel, they should be direct in explaining how their uncertainty as to how the state planners will approach their resettlement builds upon a long history of being excluded from the decisions that affect their peoples' lives. "They need to hear what's been going on," he said.

This moment was not the first or the last time that I heard someone from the Island reference historical violence and the colonial history of the United States while explaining land loss or their efforts to adapt. A number of Native American tribes and communities of color who have been pushed to what is now the edges of Louisiana's coastal zone-in large part due to histories of violence and forced displacement-are grappling with land loss, extreme weather, and the various institutional responses to those hazards as part of their long-standing efforts toward collective survival and justice. Contemporary experiences of environmental catastrophe and approaches to governing them are not experienced within a bubble. Rather, they are encumbered by memories and legacies of historical injustices. Meanwhile, state-level policy-oriented conversations about resilience planning, and community resettlement in particular, have emerged during a moment of stark realization regarding the state's capacity for coastal ecological restoration, increasing extreme weather, and future flood risks. Louisiana's 2017 Coastal Master Plan identifies a number of locations where coastal erosion, subsidence, and recurrent flooding due to extreme weather threatens traditional ways of life and future human habitability (Clipp et al. 2017). In response, scientists and planners have advanced ambitious plans to restore what is possible of the wetlands while beginning to reimagine development along the coast. Louisiana's 2017 Coastal Master Plan, however, makes clear that conservation and restoration will not always be possible, and while restoration can be expected in some areas, others will sink or wash away (see also Jankowski et al. 2017). Human and nonhuman residents of the region must continue to adapt to a shrinking coast and increasingly extreme weather. For many, this means navigating exceedingly complex policy worlds and relocating out of harm's way.

This chapter explores one of the most pressing challenges that risk reduction professionals, scholars, policy-makers, and Louisiana residents face during the implementation of community resettlement planning activities in Louisiana: the need to reckon with, on the one hand, the increasing risks to flooding and extreme weather and, on the other hand, the experiences and initiatives advanced by those whose vulnerability to these risks is connected to histories of forced displacement, dispossession of land and resources, and social marginalization. In the following pages, I describe some tensions that have emerged as long-standing tribal-driven resettlement efforts have been incorporated into state-level "coastal retreat" planning utilizing existing federal funding sources. I first describe some background to local 
policy conversations focused on resettlement as a strategy for adapting to environmental change in coastal Louisiana. Through the Louisiana Strategic Adaptations for Future Environments (LA SAFE) and state support of the Isle de Jean Charles resettlement, Louisiana's government has begun rethinking floodplain and coastal development in anticipation of increasing future flood risk and exposure to extreme weather. In their work, however, there remains a risk of disconnecting current and future exposure to coastal hazards with the development practices and legacies that have produced vulnerability unevenly among particular groups of people, such as indigenous peoples and coastal communities of color. I refer to such disconnections as ahistorical adaptation. Then, drawing on my work following the resettlement efforts of the Isle de Jean Charles Biloxi-Chitimacha-Choctaw Tribal leaders, I suggest a number of histories salient to adaptation and resettlement policy in Louisiana. I also consider the impacts of avoiding local histories of injustice and conclude with some ideas for honoring experiences and initiatives of local communities and tribes.

It is important to disclaim that my goal is not to dismiss buyout programs, community resettlement, or efforts to critically rethink floodplain and coastal development as a whole. These are important pathways for reducing exposure to hazardous environmental conditions. The multiple severe hurricanes to make landfall on the Atlantic and Gulf of Mexico coasts over the last 3 years make these tools more important and urgent than ever before, and investing predominantly on structural flood protection and environmental restoration without adequate planning for the communities in coastal Louisiana at this point would be foolish. Rather, I hope this chapter encourages reflection on a particular problem, the ahistorical framing of resilience, adaptation programs, and disaster recovery policy. This chapter also provides additional support for the growing demand for climate change and environmental adaptation policies that protect the rights of indigenous peoples and provide adequate resources to local and tribal-driven plans for resettlement.

\subsection{Context of Recent State-Level Resettlement Planning}

Since 1932, Louisiana has lost over 1866 square miles of coastal wetlands-an area nearly the size of Delaware (Couvillion et al. 2017). Floodplain development and industrialization have exacerbated subsidence and erosion throughout the state's coastal zone. An expansive web of oil and gas pipeline and shipping canals crisscross through the coastal wetlands allowing saltwater to seep into freshwater marshes and creating ecologically disruptive sediment deposits, killing flora and breaking up the soil (Turner and McClenachan 2018). Meanwhile, flood protection levees and river control structures have prevented the Mississippi and Atchafalaya Rivers from replenishing the sinking delta with new sediments (Barry 1997). The loss of land and marsh has increased Louisiana communities' exposure to hurricanes, which then erode more of the marsh as well. On top of these factors, global climate change 
poses an increasing risk of more extreme weather and sea level rise in the region (Carter et al. 2018).

As the effects of climate change become more visible, there is an emerging debate about the number of people who risk displacement as a result of climaterelated hazards (Bronen et al. 2018; Wilson and Fischetti 2010). Displacement from coastal areas has long been expected to increase due to the impacts of climate change. However, projections have recently become more dire. Rigaud et al. (2018) estimate as many as 143 million people in Sub-Saharan Africa, South Asia, and Latin America could be displaced by 2050 due to environmental changes associated with climate change. Meanwhile on the US coasts, Crowell et al. (2010) found that 8.6 million people, about 3 percent of the US population, inhabit the 100 -year flood zone, and Hauer et al. (2016) estimated that as many as 13.1 million people living in coastal counties could be at risk of displacement due to sea level rise by the next century. Recent news coverage of extreme weather also speculates the massive displacements that may be anticipated due to rising seas and extreme weather (e.g., Cusik and Aton 2017; Gohd 2018). In the aftermath of every flood, fire, or hurricane, journalists and editors dub the people facing these challenges as the next potential climate refugees - a term without legal meaning that can render the coordinated responses of communities and their collective agency invisible by implying individuals in need of saving.

A number of migration scenarios, however, already occur after, during, and in anticipation of environmental disasters-some of which empower, and are even led by, local efforts, while others marginalize and disempower those resettling. Scenarios exist for a variety of social units from individuals, to families, to neighborhoods to communities of different sizes and with varying degrees of planning. After Hurricane Katrina, for example, many relocations that were unplanned before the floods turned into more permanent resettlements as families relied on distant relatives and social ties around the country for support (Weber and Peek 2012). Residents of St. Bernard Parish, for example, moved as households to nearby areas on the north shore of Lake Pontchartrain where family members, friends, and former neighbors already relocated (Lasley 2012). Liz Koslov's work after Hurricane Sandy documented another migration pattern during which activists organized buyout groups in Staten Island, New York, to advocate for their dispersal (Koslov 2016). The Allenville, Arizona, resettlement in the early 1980s (Perry and Lindell 1997) and the relocation of Pune, India (Cronin and Guthrie 2011), were advanced by extensive community-oriented activism and with the aim of keeping people together. There are also more than a dozen other resettlements currently being planned by indigenous communities and tribal nations of North America (Keene 2017). International frameworks for planned resettlement and the sensational media representations of so-called climate refugees rarely unpack the tensions between community-based or tribal-driven resettlements and government-led planning processes. Moreover, the divergent migration scenarios mentioned above 
exist simultaneously and within overlapping geographies in coastal Louisiana-a dynamic that deserves further scholarly attention. ${ }^{1}$

There is currently no singular national agency or policy framework that guides community resettlement despite growing calls for one (Bronen 2011; Maldonado et al. 2013). The Federal Emergency Management Agency (FEMA) offers the primary form of resettlement support available pre- and post-disaster, though this support is only available for the relocation of individual households, not the entire communities (Bronen 2011; Marino 2012). The Department of Housing and Urban Development's Community Block Grant-Disaster Recovery can similarly be used to fund buyout programs. The US Army Corps of Engineers has coordinated a number of group resettlements in response to riverine flooding and the impacts of public works. These efforts have resulted in varying outcomes for the people resettling (Perry and Lindell 1997; LDOA 2015a).

Since Hurricane Sandy in 2012, design competitions sponsored by philanthropicpublic partnerships have been highly publicized for potentially offering new opportunities for communities working toward resettlement as a form of environmental adaptation. The Rockefeller Foundation and the US Department of Housing and Urban Development (HUD) partnered to sponsor the Rebuild by Design competition. This effort has been celebrated for spurring innovation and prioritizing public input throughout the design process (Collier et al. 2016). Based on perceived successes of the Rebuild by Design process, the Rockefeller Foundation and HUD administered the National Disaster Resilience Competition, which offered cities and states the opportunity to compete for part of approximately $\$ 1$ billion Community Development Block Grant Disaster Recovery funds left over from the post-Hurricane Sandy expenditure. Despite the innovation engendered by these competitions, however, HUD and local jurisdictions who implement funded projects or programs have guidelines, planning conventions, and regulatory frameworks that constrain such innovative designs. As this chapter describes below, and Laska explains in the Introduction to this volume, Chap. 1, moving from the old regulations to ones that embrace adaptation is a clunky and uneven process that involves a number of legal contradictions and potential harm for communities or tribes who have invested so much throughout their lives and potentially during the program design processes. Additionally, more research is needed to investigate the various dimensions of post-design implementation processes (for some initial critiques of Rebuild by Design, see Dawson 2017 and Flemming 2019).

Louisiana's state government is only beginning to meaningfully devote attention and resources to resettlement as an approach to environmental adaptation. Though the 2017 Coastal Master Plan incorporates nonstructural risk reduction strategies, robust investment and planning for social and cultural preservation and adaptation on our shrinking coast is much needed. The plan identifies 11 locations where, within 50 years, "flooding will be high enough to make daily life next to impossible, even without future hurricane damage" under a medium scenario of sea level rise

${ }^{1}$ I am indebted to Dr. Shirley Laska for pointing out the importance of and lack of scholarship addressing this dynamic. 
without future restoration and mitigation efforts. The identified locations from east to west are Delacroix, St. Bernard Parish; Venice, Plaquemines Parish; Grand Isle, Lafitte/Crown Point/Barataria, Jefferson Parish; Paradis, St. Charles Parish; Kraemer and Leeville, Lafourche Parish; and Cocodrie, Dulac, Isle de Jean Charles, and Lower Pointe-aux-Chenes, Terrebonne Parish (Clipp et al. 2017). Additionally, 2400 structures are targeted for potential voluntary acquisition due to their being in locations where the flood depths are forecasted to exceed 14 feet. The Coastal Protection and Restoration Authority (CPRA)'s work has received criticism, however, for not articulating a detailed buyout planning program or notifying those who live in the areas that would be targeted if one existed, and at the time of this writing, the state has yet to secure or invest the estimated $\$ 1.2$ billion necessary for the acquisitions (Wendland 2018). Policy-makers here, like elsewhere around the country, have been reluctant to embrace coastal relocation for fear of upsetting their coastal constituents as well as the administrative burdens that a relocation program would entail (Manning-Broome et al. 2015). Additionally, many communities and tribes throughout coastal Louisiana themselves do not plan on relocating and instead envision continuing to adapt in-place. Though the writing in the plan indicates people will need to move, there is no robust plan for what that process actually looks like, especially for those who plan on resettling while enhancing communal social structures or building upon traditional ways of life together in a new location.

In 2014 Louisiana's Office of Community Development began applying for funds available through the National Disaster Resilience Competition (NDRC), an initiative that has been viewed by some as an essential step in developing a more robust land-use policy to supplement the shortcomings of the Coastal Master Plan (LDOA 2015a). Among the primary goals of the competition was "to create multiple examples of local disaster recovery planning that applies science-based and forwardlooking risk analysis to address recovery, resilience, and revitalization needs" (HUD 2015). The state's NDRC funding is allocated for two programs: the Isle de Jean Charles resettlement-discussed at length below-and the Louisiana Strategic Adaptations for Future Environments (LA SAFE) program which advances resilience planning in six parishes affected by recent tropical storms and hurricanes. Louisiana's LA SAFE policy framework draft refers to areas that will experience +14 feet of flooding during a 100-year flood scenario within the next 50 years as "resettlement zones," while those that will experience between 3 and 14 feet of flooding are seen as "retrofit zones," and locations that can expect less than 3 feet of water "reshaping zones," in which development and growth will be encouraged (LDOA 2017a).

With regard to resettlement, the state "envisions a systems-based approach to community-led planning and group migration" and advances nine principles for community resettlement (LDOA 2017a, p. 14-15). The principles foreground the need for community resettlements to (1) be community-driven and voluntary; (2) be responsive to future risks and opportunities; (3) build social networks; (4) "where prudent, appropriate, and desirable, approaches should envision scenarios by which resettled communities retain access to abandoned lands for cultural, social, or economic reasons"; (5) reduce current and future risk; (6) migrations should stay 
within a single jurisdiction; (7) "embody worldwide best practices in water management, energy conservation, wetlands restoration and habitat preservation"; (8) approach development holistically to include "cultural, social, and economic growth opportunities and techniques"; and (9) consist of a "total residential abandonment of original community" (LDOA 2017a, p.15).

These principles represent a strong foundation, though there is much room for improvement in the specificity of the language used and there remain major questions as to their implementation. First, we cannot rely on bureaucratic good will and discretion. Rather, there must be legally binding policies. Second, what does risk actually entail? According to the Louisiana Budget Project, Louisiana is currently tied for second highest poverty levels in the nation, with nearly $20 \%$ of the population living in poverty, and fourth in the nation in racialized income inequality (Louisiana Budget Project 2018). Racialized and classed health disparities also persist throughout the state (Macklin 2009). The unemployment rate is higher than the national average (U.S. Bureau of Labor Statistics 2018), and many who are employed work in contingent, part-time, or low-paying positions that do not provide a living wage. Louisiana renters have long faced an affordable housing crisis, and the state was recently ranked fifth highest rent-stressed state in the country (Louisiana Housing Corporation 2019). (See Chap. 9 of this volume by Andreanecia Morris and Lucas Diaz for expanded discussion of housing risks.)

The goal of "reducing risk" cannot be isolated from broader political, economic, and social conditions. These conditions not only stand as risks themselves but exacerbate capacity to respond to extreme weather events. Regarding the fourth principle — retaining access to original land — who defines "prudent, appropriate, and desirable" and what does "access" actually mean? What other types of land tenure must be honored, including collective land ownership or continued ownership of original lands for those whose ways of life and identities are so deeply rooted in place? Finally, within these principles, there is no commitment to the protection of human rights and no reparative, restorative, or regenerative measures for the historical social production of risks and vulnerabilities that have led some people to need to resettle in the first place. The second principle even seems to discourage consideration of historical atrocities and their legacies by explicitly orienting state community resettlement activities around future opportunities and risks.

\subsection{Ahistorical Adaptation}

The above context for policy-oriented work on community resettlement demonstrates how such efforts are situated within a future-facing discourse of disaster risk reduction that contributes to the technocratic politics of climate change adaptation and resilience (see Swyngedouw 2011). Due to the severity of existing and expected environmental hazards, investing in mitigation and adaptation is necessary. There is 
also an urgent need to alter coastal and floodplain development practices and address a lack of adequate land-use planning and policy at local, state, and federal levels. When taken together, however, future-oriented discourses may reduce the complex community-oriented and tribe-driven adaptations, which are responsive to social and environmental experiences, to a technocratic process of encouraging people to move solely in relation to future flood risk as outlined in the Coastal Master Plan. When social complexities are acknowledged by state adaptation and resilience planners, they are often devoid of historical context. For example, Louisiana's policy framework draft discussed above describes their approach to resettlement as "a small-scale, targeted strategy for culturally-sensitive at-risk communities and special needs groups, including the disabled, the elderly, disaffected minority groups and very low-income populations" (LDOA 2017a). The framework does not, however, point to any processes or conditions that have led some groups to become so-called culturally sensitive or at-risk. Though the document briefly cites the atrocities of previous federal and state relocations as part of the bad "track record" of forced relocation (ibid. pp.14), it offers no examination as to why so-called minority groups and very low-income populations may have become "disaffected" in the first place.

Recent scholarship has pointed to some of the ways in which practitioners and policy-makers avoid fraught social and political histories that produce environmental risks. Katrina Kuh (2016) examines how government-sponsored adaptation strategies and outreach must sometimes separate pro-adaptation behaviors from the causes of climate change in order to engage climate change deniers, a process she dubbed agnostic adaptation. Drawing on information provided to farmers by the United States Department of Agriculture's Farm Service Agency Climate Change Adaptation Strategy, Kuh describes the ways in which adaptation tools are promoted by deemphasizing the human factors that contribute to climate change by only briefly referring to anthropogenic causes of global warming while devoting more elaborate descriptions to geophysical explanations of warming. Kuh advances important research questions as to the efficacy of agnostic adaptation and how it might create barriers to climate justice. Meanwhile Hardy et al. (2017) coined the term colorblind adaptation as a way of understanding, "vulnerability, mitigation, and adaptation planning projects that altogether overlook racial inequality—or worse dismiss its systemic causes and explain away racial inequality by attributing racial disparities to non-racial causes." Their work demonstrates some of the ways that legacies of forced migration, chattel slavery, exclusionary employment and housing policies, and local politics affect risk and adaptation possibilities for African American residents in coastal Georgia.

With the spectacular media narratives of impending massive climate displacements and the future orientation of resettlement planning as a strategy for risk reduction or climate resilience, it is worth restating what social scientists have been yelling from the rooftops for four decades: Vulnerability to natural hazards, disasters, and displacement cannot be disentangled from harmful historical social and 
political-economic processes (O'Keefe et al. 1976; Oliver-Smith and Hoffman 1999; Wisner et al. 2004). Anthropologists and other social scientists have demonstrated many of the ways that coastal governance, disaster policies, and environmental adaptation are fraught with legacies of injustice and human rights violations (Burkett et al. 2017; Hardy et al. 2017; Jerolleman 2019; Maldonado et al. 2013; Marino 2015; Whyte 2016). In an effort to address these legacies, scholars, practitioners, advocates, and resettling communities have urged government officials to guide any framework for planned resettlement by an approach that affirms and protects the human rights of those resettling (Bronen 2011; Ferris 2012; Maldonado et al. 2013).

The above scholarship demonstrates the unevenness of vulnerability, whereby people with certain social characteristics or belonging to marginalized groups are made more sensitive to the effects of hazards due to the broader inequitable political economy. Hardy et al. (2018) argue that understanding local histories is critical for recognizing (1) the ways that exposure to hazards has unfolded, (2) the uneven sensitivities of different groups within a region, (3) the cultivation of adaptive capacity, and (4) rationales for particular kinds of local adaptation. Historical perspective can also reveal barriers or constraints to future possibilities (ibid.). According to the authors, by ignoring local histories, "we risk missing many factors that contribute to vulnerability and suboptimal adaptation measures" (Hardy et al. 2018, p. 10). Ignoring these histories also implicitly blames those who must deal with the immediate impacts of unsustainable aspects of our civilization for the risks they face (Tierney 2014). Inspired by the important critiques above and the questions raised by Kuh as to the efficacy of agnostic adaptation, in this chapter I hope to contribute to a conversation about how the institutionalization of environmental adaptation as an ahistorical discourse actively produces new kinds of vulnerability while aggravating existing experiences of injustice.

\subsection{Historicizing Isle de Jean Charles Resettlement Planning}

In the following sections, I reflect on my work following the Isle de Jean Charles Biloxi-Chitimacha-Choctaw Tribal leaders' resettlement efforts to consider how particular historical processes are relevant to current community resettlement planning in Louisiana. Not all of the potentially important local, regional, national, and international historical threads that could help one understand adaptation and resettlement are reflected in this chapter. However, I have found that the following histories are especially salient within the particular context in which I did my research: (1) legacies of environmental injustice, (2) recent experiences of displacement, (3) US settler colonialism, and (4) the Tribal-driven planning process that immediately preceded and directly contributed to Louisiana's successful application to the National Disaster Resilience Competition. 


\subsubsection{Extraction, Exclusion, and Injustice}

There is no way to really understand the Isle de Jean Charles resettlement effort without reckoning with the tragic social and environmental impacts of extractive industries and regional development on and around the Island. Over the last 75 years, regional oil and natural gas infrastructure and development has transformed the place (Austin 2006). Companies like Apache, BP, Texaco, Chevron, and Shell have devastated the surrounding landscape with pipeline canals and oil and gas infrastructure (Maldonado 2018). (See Fig. 6.1 for a map of oil and gas infrastructure density throughout the region.) The Island itself sits between multiple oil and gas fields and is surrounded by pipeline canals, and those from the Island point to a long history of land grabs by land and oil companies preceding the current environmental crisis (Maldonado 2018). Since 1955, $98 \%$ of the Island's landmass has sunk or washed away (CPRA 2017). Over 22,000 acres of land and surrounding marsh have been lost (LDOA 2015a). According to the summary of a satellite imaging study conducted by the Earth Resources Observation and Science Center and United States Geological Survey, "Once 5 miles wide and filled with lush cypress groves and cow pastures, barely a half square mile of the Island remains above water" (USGS 2017). A former state senator explained that the Island road (built in 1953) sits on "some of the most unstable land in all of coastal Louisiana" (Reggie Dupre, personal communication, November 2017). According to Tribal leaders, the Island flooded from six major storms and multiple less severe storms since 2005. Maldonado et al. (2015) and other critics have referred to the region as a "sacrificial zone of resource extraction" due to the exploitation and subsequent disaster produced by industrial development.

Flood mitigation projects have also had devastating social and environmental consequences, and the Tribe's resettlement efforts are actually rooted in impacts of

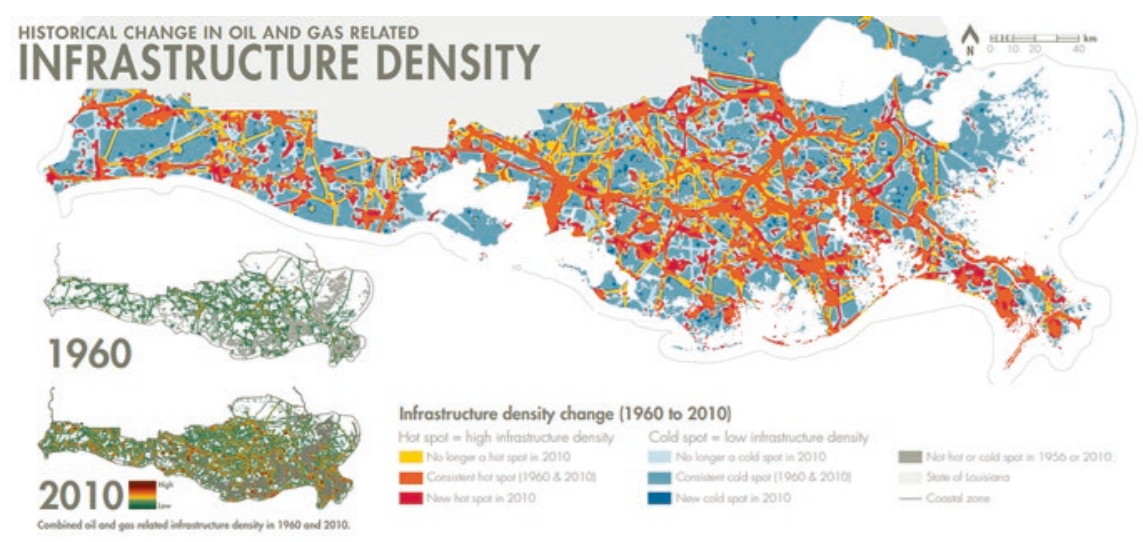

Fig. 6.1 Maps showing historical change in oil- and gas-related infrastructure density in southern Louisiana between 1960 and 2010 as presented in a 2016 synthesis report by The Water Institute of the Gulf 
one effort to address coastal hazards regionally. In 1998, the US Army Corps of Engineers rerouted designs for a 98-mile levee, the Morganza to the Gulf Risk Reduction System. The new route excluded the Island and a number of other communities down the bayou further materializing and intensifying their vulnerability (Maldonado 2018). The realignment increased the risk of flooding for those who remained outside of its protection (USACE 2013) and, along with the severe 2002 storms, led the Tribal Council to begin planning their resettlement to reunite their Tribe and ensuring the survival and growth of their culture together (Maldonado 2018). The US Army Corps offered to relocate the Island residents but backed out after demanding a 100\% consensus in favor of relocation among Island residents (Simon 2008) - a naive ideal given the complexities involved in any relocation decision-making process. Without social scientists in Corps staffs (other than economists and archaeologists), the Corps could not have appreciated the unrealistic nature of the demand. ${ }^{2}$ Then in 2008, Tribal leaders appealed to Terrebonne Parish for CDBG funds to support a resettlement that would reunite their already displaced tribal citizens and support their cultural and social revitalization, but the effort fell apart when confronted with resistance from the white residents adjacent to where they were hoping to move (Maldonado 2018). Tribal leaders continued to organize both for resettlement and sustaining the Island despite these disappointing setbacks from potential government partners.

The above histories of injustice are often obscured within state restoration and resilience planning. Colten (2017) compared how the causes of wetland loss are discussed in a number of reports released since 1990. He found that over time these reports have reframed oil and gas companies from culpable damage to the wetlands to those also in need of support and protection from environmental change. According to Colten, more recent reports emphasize the role of subsidence while refusing to acknowledge the impact of oil and gas pipeline and navigation canals in destroying the marsh (Colten 2017, p. 706). The Coastal Protection and Restoration Authority has continued to obscure causes in their efforts to build broad public support for restoration. The Coastal Master Plan, and subsequently the LA SAFE framework, emphasizes the importance of "the working coast" and euphemistically provides support for the interests of industrial actors. Over 20\% of the nation's oil and gas, and $90 \%$ of the offshore oil, comes from or passes through the region for processing and refinement, and many of those made most vulnerable by oil and gas industries rely on them for their livelihoods (Clipp et al. 2017). This bind may discourage critique and makes the movement for a just transition from fossil fuels particularly relevant to coastal Louisiana.

Adaptation strategies that avoid addressing these histories of injustice while highlighting the "working coast" dynamic accommodate oil and gas industries by not holding them accountable for the destruction they have caused (Randolph 2018; Turner and McClenachan 2018). They also potentially stifle support for a muchneeded just transition from fossil fuels in a key place of extraction, production, and transport. Moreover, these frames reproduce the notion that federal investment in

\footnotetext{
${ }^{2}$ Personal communication with Shirley Laska
} 
resilience and resettlement planning may constitute a "handout" by neglecting the price that the Isle de Jean Charles Biloxi-Chitimacha-Choctaw Tribe and other coastal communities who have been made vulnerable by extractive industries and flood protection measures have already paid (Jessee 2016). They also obscure rationales and thus potential support for many of the social dimensions of the resettlement, which, for the Isle de Jean Charles Biloxi-Chitimacha-Choctaw Tribe, have included reuniting those who are already displaced or have moved from the Island, building energy and food independence, and bolstering the Tribe's capacity to assert their rights of self-determination and sovereignty (LDOA 2015a).

\subsubsection{Ongoing Displacement and the Complex Notion of Community}

Another challenge for resettlement as a form of environmental adaptation involves addressing recent histories of displacement and complexities surrounding the notion of community. Displacement has dramatically changed life on the Island, and decades of outward migration have transformed the composition and social dynamics of the Isle de Jean Charles community. There were 78 houses and approximately 325 people living on Isle de Jean Charles in 2002, and 10 years later only about 25 houses and 70 people remained there (Maldonado 2014). Over 75 percent of the Island community have been displaced over this multigenerational environmental catastrophe of land loss. Many tribal members moved from the Island because regular flooding on the road kept them from off-Island jobs, while others recounted moving due to a decline in regional industries like shrimping and trapping in the 1980s. Though some Isle de Jean Charles Biloxi-ChitimachaChoctaw Tribal Council and elders still live on the Island, much of the tribal leadership now lives just a few miles away in Pointe-aux-Chenes and Houma. Displaced Tribal members however maintain important social connections with their family and former neighbors who remain on the Island. The Island remains a cohesive aspect of displaced Tribal members' identities and social memory, and the expansive networks of former and current Island residents remain an essential aspect of resilience (Simms 2016).

Many self-identified communities and tribes in Louisiana who may consider resettling are likely already experiencing this kind of displacement (Colten et al. 2018). Numerous locations along the state's coast have seen extensive outward migration over the last 20 years: Dulac has lost 29\%, Golden Meadow 3\%, Lafitte $31 \%$, and Buras-Triumph $67 \%$ of their populations between the years 2000 and 2010 (see Fig. 6.2). Coastal storms most often diminish local populations in "waves" after strong hurricanes rather than one event causing the abandonment of a location in one storm (Laska, personal communication, April 16, 2018). Dr. Shirley Laska likens it to the rate of coastal land loss which occurs in "waves" during powerful storms, not a little each year, but rather surging. Relocation decisions are often 


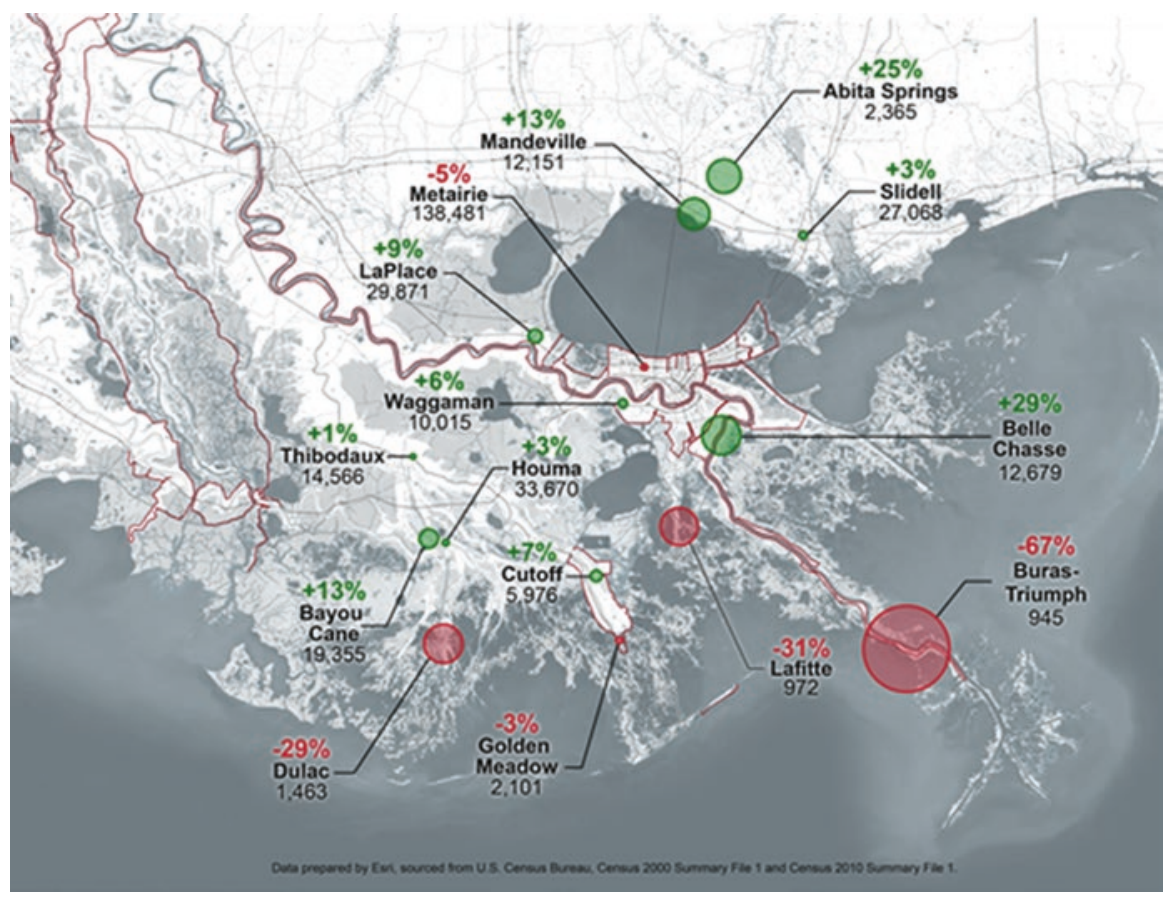

Fig. 6.2 Map showing regional population shifts in southeast Louisiana between 2000 and 2010. (Image source: LA SAFE)

linked to the accessibility of schools or work, as younger people often leave, while elders have remained in place (Colten et al. 2018). Additionally, long-time residents often cannot afford to elevate their flood-impacted homes, continuing their vulnerability and preventing them from affording the flood insurance. According to Hobor et al. (2014), Louisiana residents who work in coastal industries increasingly travel from residences inland to their coastal job sites. Those who work on the coast, such as fishers, must assess how far inland they might live for safety while commuting in reverse for work (Laska et al. 2015). Meanwhile, since the 1970s, coastal areas like Cocodrie and Isle de Jean Charles have also seen an influx of wealthy white "weekend warriors" who can afford to maintain camps along the coast and enjoy the landscape for recreational activities-a dynamic that stirs concerns of coastal gentrification among the historic residents (Peterson and Maldonado 2016; Solet 2006). ${ }^{3}$ Additionally, research into development-forced displacement and resettlement has revealed the risk of further severing social ties mediated by relationships to place, a process described by Michael Cernea (1997)

\footnotetext{
${ }^{3}$ For readers unfamiliar with "camps" in Louisiana, they are often more like lavish fishing vacation homes with docks and modern amenities than, say, a tent or a yurt. There is an incentive for parishes to encourage camp development for more tax dollars than low-lying homes, which are often valued at much less and have homestead tax exemptions.
} 
as social disarticulation. Displaced people who experience disrupted networks, shared rituals, religious institutions, kinship structures, and social cohesion experience consistently worse outcomes during resettlement processes (OliverSmith 2009). In coastal Louisiana social disarticulation caused by displacement may already be underway and indeed has been a major rationale for Isle de Jean Charles Tribal leaders to use resettlement to reunite their Tribe.

"Community" is a slippery and contested concept in any context, and many scholars have debated its utility and application (Titz et al. 2018; Williams 2002). Brett Williams (2002) reviews the myriad of ways community can be produced through shared experiences, senses of place, cultural practices, memories, and relationships but describes how bonds of community are constantly negotiated, contested, and adjusted. State agencies and international frameworks, however, often advance narrow notions of risk and vulnerability that emphasize geographic exposure to hazards over social risks (Faas 2016). These frameworks also inscribe notions of community as bounded geographic units (e.g., Clipp et al. 2017; LDOA 2019a). Media coverage of land loss that relies on particular visual tropes, like aerial shots of the Island, may also reinforce such notions of vulnerability and community, obscuring broader political-economic causes of vulnerability and geographically expansive yet intimate social networks of care critical for resilience in the region. After reviewing the use of "community" throughout development and disaster risk reduction, Titz et al. (2018) conclude that the term should be abandoned in such contexts because of the harm that can be caused by its vagueness. They argue that more specific identifiers should be used. The ambiguities of "community" are part of a set of conditions that has potentially enabled state planners to reduce their commitments to and partnership with the Isle de Jean Charles Biloxi-ChitimachaChoctaw Tribe after the award money for the resettlement was garnered. Divergent notions of "community" as location-specific versus based on tribal identity have troubled the Isle de Jean Charles resettlement process (Jessee Forthcoming). While the Office of Community Development considered geographic exposure to hazards at length in their application for NDRC funds, they also importantly operationalized the Isle de Jean Charles Biloxi-Chitimacha-Choctaw Tribe as the community during application phases, building on the long-standing tribal resettlement efforts that had preceded the competition.

Community resettlement planning efforts need to take careful steps toward the rearticulation of potentially fragmented or strained already displaced self-identified communities. Investing in the enhancement of communal structures and honoring collective identities and their histories early and throughout resettlement processes may provide a pathway to addressing social disarticulation. After Hurricane Katrina, those who relocated clustered into family and neighborhood groups in their new locations (Lasley 2012). The same is true among the tribes of lower Terrebonne Parish (Maldonado 2018). Clustering might be instrumental in the long-term wellbeing of coastal peoples as they move inland to a somewhat foreign culture. The historic migrations of Europeans to US cities over the last two centuries often also led to clustering of the new migrants in urban enclaves, which informally supported social networks, economic needs during transition, and personal preferences (Logan 
et al. 2002). Over the first 3 years of the state's administration of federal support for the Isle de Jean Charles resettlement, there has been much more attention devoted to outreach to individual households on the Island, residential options, and the overall site design, rather than specific planning for the continuation of tribal and communal institutions and organizations from the Island (Jessee Forthcoming). The tendency to focus on individual households at the expense of complex social realities of community is documented in the administration of other community resettlement processes as well (Wilmsen and Webber 2015). According to Cernea (2000), one way to mitigate social disarticulation, which I think might also support clustering and nurture social networks that may have grown distant throughout the years of displacement, is to establish common property and communal facilities and programing at new locations early on in the process and to engage with communityoriented or tribe-based organizations rather than having the focus be so oriented around individuals throughout the planning processes.

Despite the trickiness of defining community, social scientists have also stressed the importance of existing community-based institutions, organizations, leadership, and expertise. Meaningful partnerships with community leadership have been essential during post-disaster recovery (Nelson et al. 2007; Laska et al. 2010). Indeed, the successes attributed to well-known community resettlements in North Bonneville, Washington, and in Valmeyer, Illinois, can be attributed to the ability of existing leadership to maintain continuity throughout the planning processes (Comstock and Fox 1993). Perry and Lindell (1997) also found that the ongoing efforts of a nonprofit, the Allenville Citizens for Progress, representing the unincorporated people of Allenville, Arizona, were essential in the successes of their relocation from the Gila River floodplain. Existing leadership, like that of the Isle de Jean Charles Biloxi-Chitimacha-Choctaw Tribal Council, is invaluable, and often demonstrate a history of influence and resource provision, maintain shared memories and knowledge about local worldviews and higher incomes, and have access to social networks for further support into the future. Moreover, local community-based or tribal leadership is likely more committed to the future well-being of community members than government planners whose investment is typically limited to a grant, program, or employment timeline.

\subsubsection{Reshaping Louisiana's Coastal Frontier: From Doctrine of Discovery to Climate Catastrophe}

Contemporary environmental adaptation, US settler colonization, and struggles for indigenous self-determination are deeply intertwined. First of all, as Chief Naquin explained in Victor's kitchen, the Isle de Jean Charles Biloxi-Chitimacha-Choctaw Tribe descends from ancestors who survived Indian Removal Act-era violence by resettling down the bayou, away from and invisible to the nearby settler society. In addition to indigenous peoples, Vietnamese families, who resettled in the Mississippi 
Delta through the 1970 s through wartime refugee programs; Cajuns, whose ancestors were displaced from Canada; and African American communities who trace their histories to those who escaped the atrocities of chattel slavery also live in potential resettlement zones of coastal Louisiana (Dalbom et al. 2014; Laska et al. 2015). Legacies of forced displacements have long-term social, economic, and health consequences, as researchers have demonstrated by examining the longitudinal and intergenerational effects of Indian relocation (Walls and Whitebeck 2012), Japanese internment (Nagata et al. 2015), the holocaust (Matz et al. 2015), and urban renewal (Fullilove 2005). The histories of colonialism, forced migration, slavery, Jim Crow segregation, and other forms of racialized dispossession continue to shape where people live in relation to coastal risks, how sensitive communities are to hazards, and the extent to which oppressed peoples have the resources to adapt.

Additionally, the archaeological record indicates a long history of regular indigenous migrations that involved the movements of small kinship units and much larger political groups between coastal areas, along bayous, and further inland for many reasons including as a response to regular flood events (Sassaman and Anderson 2004; McCintire 1954). Recent anthropological and social science research has examined this longer history of migration as an adaptation strategy among indigenous peoples, the impact of settler colonial formations, and the need to recognize the wisdom passed on intergenerationally among indigenous peoples (see Marino 2012; Whyte 2016; Wildcat 2009). Elizabeth Marino (2012) draws on ethnographic work alongside the Inupiat people of Shishmaref, Alaska, documenting how colonial infrastructures like roads, post offices, and schools led to sedentarization of previously mobile communities and created risk by developing increasing reliance on now failing infrastructure. Kyle Whyte (2016) expands upon Marino's work describing how 500 years of colonial treaties, laws, and institutions have threatened indigenous adaptation by imposing regimes of containment and the erasure of indigenous social institutions. These scholars demonstrate both that colonial development has produced conditions that have exposed indigenous communities to climate change-related hazards and undermined traditional effective modes of adaptation. They also describe the harm that is produced when colonial models of communal life, which align more with individualism and capitalist social relations, are imposed and replace indigenous modes of social organization. Contemporary initiatives to adapt as a whole tribal community and through traditional forms of organizing, like the Isle de Jean Charles Biloxi-ChitimachaChoctaw resettlement, extend and build upon the survival and adaptation to social change throughout histories of violence, forced displacement, and physical and social marginalization.

The historic and ongoing dispossession of lands from indigenous peoples provides necessary historical context to current issues of land tenure and migration in settler colonial states like the United States (Tuck and Yang 2012; Wolfe 2006). US claims to sovereignty are rooted in the Doctrine of Discovery-a set of principles established among European monarchies in the mid-fifteenth century that attaches land rights to the "act of discovery." As recently as 2005, the Doctrine of Discovery 
was referenced by the US Supreme Court in a challenge to the land rights of the Oneida Nation (Dunbar-Ortiz 2014). A fundamental history of the United States has been one of treaties, legal actions, and genocidal violence by European and White American settlers aimed at the dispossession of land from indigenous peoples and establishing the conditions for white supremacy, capitalist, and imperial expansion in the United States and around the globe (Ibid.). This history has created apocalyptic conditions for the indigenous nations who previously and still inhabit this land (Estes 2019; Whyte 2016). France, Spain, and the United States have all established colonial governments in the region of Isle de Jean Charles, and colonial infrastructure, private property regimes, and land grabbing by developers and oil and gas companies established key conditions for the current ecological crisis and the tribaldriven efforts to resettle.

Restoring capacity for seasonal habitation, communal gathering, subsistence, and the reinvigoration of traditions are thus potentially essential resettlement planning activities. Such considerations and the retaining of Island land have long been prioritized in the discussions among the Isle de Jean Charles Biloxi-ChitimachaChoctaw Tribal leaders and their partners (Maldonado et al. 2015; Peterson and Maldonado 2016). Retaining previously held territory is seen as critical for the cultural survival of many indigenous communities and nations like the Isle de Jean Charles Biloxi-Chitimacha-Choctaw Tribe (Burkett et al. 2017; Marino 2015). The fundamental logic behind CDBG and FEMA buyout programs, however, is that a place has been identified as geographically, physically at risk to recurrent damage and therefore should not sustain future habitation. FEMA and HUD's general approach to buyouts for hazard mitigation in floodplains aims at returning residential areas exposed to repeated disasters to open space (see 44 C.F.R. $§ 79.62018$ and Notice of National Disaster Resilience Competition Grant Requirements 81 Fed. Reg. 109, June 7, 2016). Typically, this involves demolishing structures and residents giving up their property in exchange for the buyout funds. The Isle de Jean Charles Biloxi-Chitimacha-Choctaw Tribal Council's adaptation goals have included the continued ownership of family parcels and protection of the Island while also investing in their collective future elsewhere therefore clash with federal agency expectations and regulations. After pressure from Tribal leaders and Island residents, state officials in charge of administering NDRC funds for the Isle de Jean Charles resettlement have taken some steps to ensure the continued "access" to the Island "for ceremonial, cultural, historic and recreational purposes" (LDOA 2019a, pp.7). At the time of this writing, however, there remain important questions regarding the future of Island properties, and tribal leaders have concerns as to restrictions on that access and potential continued ownership.

There are a broad set of questions engendered by the Isle de Jean Charles resettlement and the historical dispossession of indigenous lands. In terms of immediate planning, what may motivate those who administer federal grants to advocate for amendments that embrace adaptation innovations when they depart from established regulations, and how might tribal and community leaders inform that process? More importantly, what will it take to institutionalize the legal and governance innovations needed to implement plans developed by communities and tribes? How 
will policy-makers ensure that adaptation programs will not perpetuate the dispossession of tribal lands or further fragment traditional relationships to place? How can adaptation planning support and extend indigenous peoples' traditional forms of land tenure? And how will such programs provide reparations for the historical forced migrations and dispossession of indigenous peoples' lands sponsored by the US and local governments and private sector?

\subsubsection{Between Recognition and Retreat}

Political recognition of tribal sovereignty has become important to many indigenous nations as they adapt to coastal land loss (Katz 2003; Ferguson-Bohnee 2018; Sneath 2018). The policy worlds of tribal recognition are complex and contested, and many indigenous leaders and scholars have criticized both the intentions and impacts of the federal recognition process in the United States. One set of criticisms points to the petition process administered by the US Bureau of Indian Affairs. The agency demands that petitions for acknowledgment rely on written historical evidence despite the oral traditions of many indigenous nations and the misrepresentations that proliferate among colonial record-keeping and academic analyses (Miller 2004). Additionally, the petitions must present narratives that demonstrate community, political influence, and other specific criteria in a way that satisfies what the US government considers legitimate indigenous identities, histories, and forms of social organization. The criteria for petitions for federal recognition are often seen as rooted in racist colonial ideologies rather than the experiences, expressions, notions of belonging, and social institutions maintained traditionally by diverse groups of indigenous peoples (Barker 2011). Additionally, the petitions are judged by ambiguous standards that seem to shift depending on who is applying for recognition (Miller 2004). There is also a set of criticisms that point to the many examples of federal recognition processes dividing indigenous groups over limited resources (Miller 2004). Moreover, once a Tribe has submitted a petition for recognition, they must wait sometimes years for a response, and crafting a compelling submission requires enormous investment of time and money for legal and archival research that can influence, overwhelm, and undercut indigenous leaders and indigenous social efforts (Den Ouden and O'Brien 2013). In 1992, anthropologist William Starna referred to the federal recognition process as "administrative genocide."

Despite these critiques, federal recognition may also provide needed resources to Louisiana's coastal and bayou tribes. Federal recognition might enable local tribes to protect what remains of their eroding and subsiding homelands (Katz 2003; Rivard 2015). It would also open up the possibility for further partnerships among the tribes and government agencies to implement adaptation and resilience planning or for disaster assistance. A number of regulations describe federal recognition as part of the eligibility for various kinds of disaster recovery and other kinds of public support (see 44 CFR $\S 201.2$, Emergency Management and Assistance, and 2 CFR 
$\S 200.54$, Grants and Agreements). Isle de Jean Charles Biloxi-Chitimacha-Choctaw tribal leaders have been pursuing federal recognition while also planning their resettlement, devoting an enormous amount of time and resources to both. For example, while Tribal leaders were grappling with the various components of the state's planning process, they continued archival research and confirmed their rolls - a core requisite of the federal recognition petition process that also provided proof to the state that the Island residents were overwhelmingly members of the Tribe. The urgency and logistic demands of both resettlement and recognition weigh heavy on Tribal leaders, leading to a dilemma as to where to devote energy at any given moment.

Some state governments, including Louisiana, have also formally recognized the existence and rights of indigenous nations, even when they are not federally recognized tribes. The processes by which recognition is administered and the rights ensured by so-called state recognition vary among those states (Koenig and Stein 2013). The Isle de Jean Charles Biloxi-Chitimacha-Choctaw Tribe is one of 11 nonfederally recognized tribes currently recognized by the state government (LA Indian Affairs 2018), having first been acknowledged by the state legislature in a 2004 senate resolution passed to provide the Tribe access to education and healthcare opportunities (Sen.Con.Res. 105 2004). They are also one of the 15 indigenous nations recently invited to participate in the Louisiana Native American Commission by recent state legislation (LA ACT 102 HB 660 2018).

The state of Louisiana, however, has been inconsistent in their approach to recognizing the rights of indigenous peoples. Koenig and Stein (2013, p. 133) observed that state recognition in Louisiana was described by the former director of Louisiana's Office of Indian Affairs as establishing a "government-to-government relationship" between the state government and the tribes that lived within the state's borders. At some point after their interview, during Bobby Jindal's time as governor, the Office of Indian Affairs became inactive. In 2017 and 2018, the Edwards administration and state legislature took some initial steps to further develop and clarify the meaning of state recognition (e.g., LA ACT 102 HB 660 2018). During a recent interview, however, one Louisiana state planner working on the Isle de Jean Charles resettlement pointed to the limits of state power in recognizing tribal sovereignty and rights to self-determination. He explained that only if the Isle de Jean Charles Biloxi-Chitimacha-Choctaw Tribe were federally recognized, "We would have government to government relations. But we cannot approach it that way. It is not legal." This reported inability of state government, however, runs counter to interpretations of the US Constitution and Indian law by government officials in at least one other state (see Lindemuth 2017) and forecloses an exploration of how state planners and policy-makers can honor the inherent sovereignty of non-federally recognized tribes. Legal scholars have argued that state governments have considerable flexibility as to how they approach and honor the rights of state-recognized tribes (Cohen 2005). For example, some states maintain special programs to serve non-federally recognized tribes, and one has even established a legal process for devoting land to non-federally recognized tribes (Cohen 2005). 
The state's inconsistency with regard to tribal recognition has haunted the Isle de Jean Charles resettlement process. During a recent state-held resettlement planning meeting, I asked an Office of Community Development planner about the minimal references to the indigenous heritage of the Island in recent resettlement program guidelines and designs. As a counterpoint, he pointed me to a recently produced document, which, according to him, appreciated this important history (LDOA 2019a). The document, however, presents a very narrow historical overview in three brief bullet points that begin in 1979, neglecting a much longer documented history of indigenous habitation of the Island and any celebration of indigenous adaptation and life ways. Moreover, according to tribal leaders, they were not consulted in crafting this representation of their history. The final bullet point in the documentwhich, again, was conveyed to me as evidence that the Office of Community Development appreciates the indigenous heritage of the Island-explicitly calls into question the state's recognition of the Isle de Jean Charles Biloxi-ChitimachaChoctaw Tribe by pointing out the specific aims and scope of the 2004 state senate resolution to ensure their access to educational and healthcare opportunities, as if to notify readers that state recognition is irrelevant to the Tribe's resettlement efforts. The same 2004 senate resolution, however, also articulates a broader state policy "to provide for recognition of Indian tribes within its borders, to support their tribal aspirations, to preserve their cultural heritage and improve their economic condition and to assist them in the achievement of their just rights" (Sen.Con.Res. 105 2004). Why did the Louisiana Office of Community Development emphasize the narrow focus of one aspect of the legal act in their resettlement background and overview?

Tensions over the role of state and federal recognition reflect the difficult position in which tribal leaders have been placed. Disparate "opportunities" within complex and contradictory policy worlds constrain actual possibilities for indigenous planning and resilience. The Isle de Jean Charles Biloxi-Chitimacha-Choctaw Tribal Council is struggling for self-determination while caught between notions of community, between a state agency and the ambiguities of state and federal policy, between state and federal government approaches to recognizing indigenous sovereignty, and between the politics of tribal recognition and the liberal and colonial politics of so-called "managed retreat." Ahistorical adaptation enables the continuation of administrative barriers and prevents indigenous peoples' in the United States from realizing their rights to self-determination, historic lands, and cultural preservation in times of climate change. In order to provide a meaningful opportunity for coastal and bayou tribes in Louisiana to protect their heritage and land and ensure their cultural survival for generations to come, state and federal governments must quickly and fully recognize the sovereignty of each of the tribes, who are seeking formal recognition. The United States must also become a full signatory and legally adopt the United Nations Declaration of Rights of Indigenous Peoples and protect the rights described therein, which include the right to self-determination, right to land, right to protect historic sites, and the right to receive redress from experiences of land dispossession, forced assimilation, and the deprivation of distinct cultural values or ethnic identities (UN General Assembly 2007). 


\subsubsection{Reframing Resettlement}

The most urgent form of ahistorical adaptation, however, for Isle de Jean Charles Biloxi-Chitimacha-Choctaw Tribal leaders has emerged as government planners and their contractors have not adequately honored the existing resettlement plans driven by tribal leaders long before resources arrived. Isle de Jean Charles BiloxiChitimacha-Choctaw Tribal leaders had been actively working on resettling inland and reuniting their displaced Tribe for over a decade prior to the National Disaster Resilience Competition. The Tribe's pre-NDRC resettlement efforts are documented extensively by journalists, academics, and filmmakers (Jessee 2015; Maldonado et al. 2015; Simon 2008). Despite multiple setbacks in the previous efforts the US Army Corps and Terrebonne Parish described in a previous section of this chapter, the Tribal Council has continued to search for resources and pathways to reunite their people and ensure their future inland - an effort described by Tribal Executive Secretary, Chantel Comardelle, during an interview as "creating a living and active bridge from our ancestral land to the new Isle de Jean Charles Tribal community."

Secretary Comardelle had lived on the Island until she was 4 years old. Her mother and father - the current Deputy Chief of the Tribe-left in the mid-1980s after Hurricane Juan. She had developed chronic respiratory problems from mold that proliferated from repeated flooding. Secretary Comardelle has a full-time job outside of her unpaid role supporting the Tribe and regularly works all hours of the night on resettlement planning, federal recognition, and other tribal-driven initiatives. She often participates in planning conference calls while at her children's various sports practices and gymnastics meets. In addition to all of this, in 2017 Chantel completed a Museum Studies Certificate Program from the Institute of American Indian Arts. Her aim has been to learn curatorial skills that will help future generations absorb their heritage and maintain relationships to their ancestral Island, even if the land mass erodes away. Secretary Comardelle is someone I often think of when I encounter the term "climate refugees" attributed to her Tribe. The term fails to capture the amount of time, work, planning, and passion that she and the Tribal Council have put into their resettlement over the years. It dehumanizes the Island people by representing them only in terms of vulnerability and environmental risk, rather than as whole human subjects with multiple dimensions, experiences, relationships, aspirations, fears, and dimensions of their identities. Nor does it capture the reality that the effort is with the entire tribal social organization and cultural survival in mind, not individuals fleeing one particular hazard. According to Secretary Comardelle, "For us, resettlement is an act of cultural survival."

In 2010, Tribal leaders began working with long-time collaborators at the Lowlander Center - a nonprofit organization that uses participatory action research to support the efforts of a number of bayou communities and tribes. Together, they assembled a team of academics, architects, indigenous leaders, and other professionals who could provide resources, support, collaboration, and fellowship as the Tribe pursued their resettlement. The Tribe, Lowlander Center, and other 


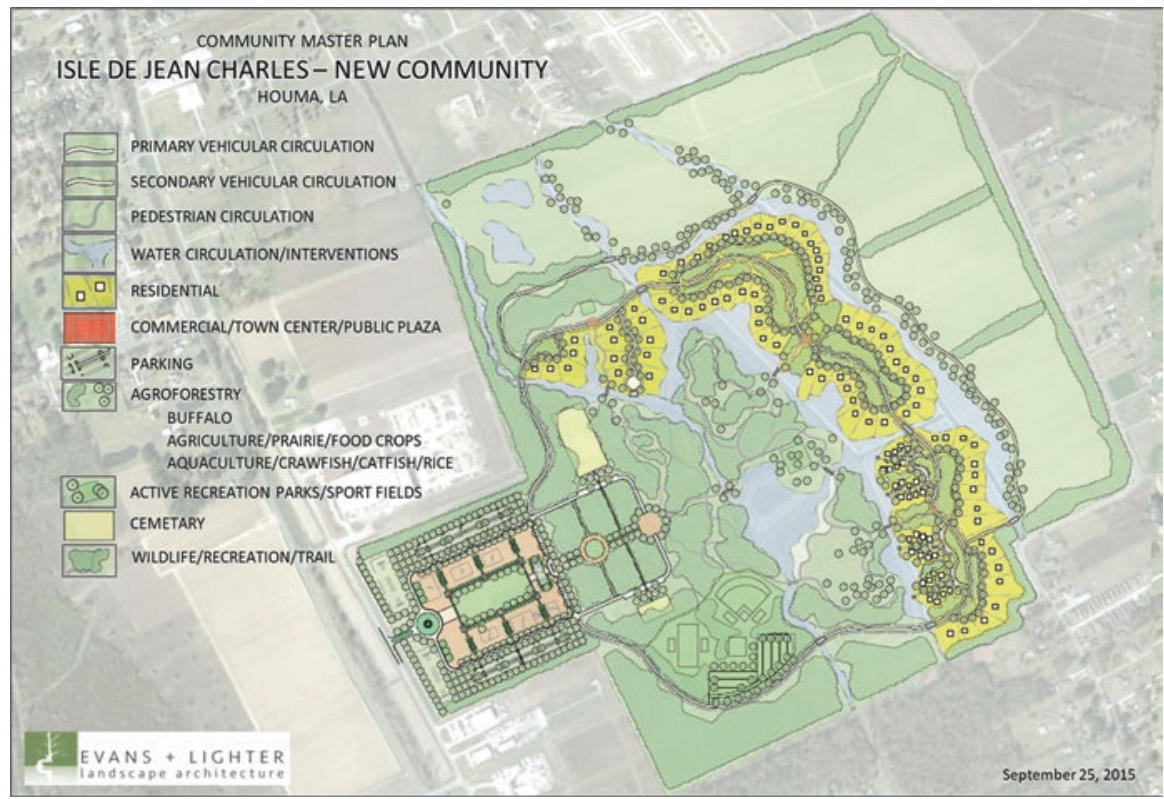

Fig. 6.3 A conceptual plan for the relocated Isle de Jean Charles community includes about 100 homesites and a village center. (Image courtesy of Evans + Lighter Landscape Architecture)

collaborators planned for key tribal institutions like a museum, tribal cultural and community center, health facilities, and gardens. Their planning efforts embraced renewable energy, mitigation standards for infrastructure and design, tribal governance capacity building, and tribal-driven economic development principles (see Fig. 6.3 for one pre-NDRC rendering produced by Evans \& Lighter Architecture in collaboration with tribal leaders and their resettlement partners). When I began working with Tribal leaders and their resettlement partners in late 2014, they were in the midst of conducting extensive outreach to build support for their tribal resettlement plans and synthesizing existing literature in sustainable development, resettlement, and resilience to use as a baseline for critically analyzing their own planning process (Jessee 2015). The tribal-driven resettlement work has been celebrated internationally as the Tribal leadership has garnered awards like the Mississippi-Alabama Sea Grant Consortium's "Spirit of the Community" Award, the US Environmental Protection Agency's "Guardian of the Gulf Award for Environmental Justice," and the Rising Voices "Bob Gough Climate Justice in Action Award." Additionally, the Lowlander Center was one of five awardees of the 2018 Climigration Network Award for their approach to community relocation.

After years of struggling to secure financial resettlement support, in 2015 the Isle de Jean Charles Biloxi-Chitimacha-Choctaw Tribe and the Lowlander Center partnered with Louisiana's Office of Community Development (OCD). The Tribal Council, Lowlander Center, and their network of scholars and architects attended public meetings and multiple planning sessions with the state agency, contributing 
extensive time and labor to the State's process of crafting a successful submission to the National Disaster Resilience Competition-an effort that garnered $\$ 48.3$ million in federal funds to support their tribal resettlement (LDOA 2015a). The application importantly spoke to the social as well as environmental concerns of tribal leaders by assuring that "All factors of design and process will help to support and enhance tribal identity, sovereignty, and dignity" (LDOA 2015b, pp. 107). Once the award was granted, the Isle de Jean Charles Biloxi-Chitimacha-Choctaw Tribe and Lowlander Center each received partnership letters from Louisiana's Office of Community Development (OCD) that thanked them, acknowledged their contributions to crafting a winning application, and ensured a continued partnership.

It appears as though state planners and US Department of Housing and Urban Development officials, however, did not thoroughly understand the social and historical complexities of the Island or the contested space that had emerged from decades of land grabs, displacement, gentrification, and the social demands on multiple tribes who inhabit the region. Soon after the NDRC award was announced, some of the complex realities of the Island as a social space became evident to state officials by way of a letter to the Governor from the Chief of the United Houma Nation-another indigenous nation from the region-expressing their concern over being excluded from the State's plans for using federal resilience funds despite their also having ties to the Island (Batte 2016). ${ }^{4}$ The reason the United Houma Nation was not included in Louisiana's initial NDRC application remains unclear, though Crepelle (2019, pp. 27-28) suggests it might be the result of the United Houma Nation having not sent a representative to state-led meetings during the application process. State documentation portrays at least one person from the Tribe in attendance at a phase II workshop (LDOA 2015c, p. 350). However, the documentation does not capture the rationale behind the state's phase II outreach process or the content of specific conversations during that period. This confusion points to how critical it is for state agencies to more fully appreciate local histories and complex social relations before developing and committing to programs, something that the timelines of design competition application processes and the pace of grant cycles discourages.

Louisiana's Office of Community Development began redefining the character, scope, and beneficiaries of the resettlement after the letter from the United Houma Nation. What was in the application framed as a tribal resettlement that included current and former Island residents (most of whom also live in low-lying areas in the region that also experience flooding) became predominantly focused on the current Island residents as individuals, regardless of tribal identity. According to a fact sheet circulated by the office:

Phase II of the state's NDRC application specifically references the Isle de Jean Charles Band of Biloxi-Chitimacha-Choctaw. This reference was made under the belief that all inhabitants of the Island affiliate with this tribe. There are apparently also members of the United Houma Nation living on the Island, and there may be Island residents who don't

\footnotetext{
${ }^{4}$ The experiences and aims of the United Houma Nation's Tribal government and citizens are beyond the scope of the research that informs this chapter.
} 
affiliate with any tribe. As such, specific tribal membership will not be a requirement for inclusion in the resettlement, as the state's objective is the resettlement of all willing members of the Isle de Jean Charles community, irrespective of any familial, cultural or tribal affiliation. (quoted in Crepelle 2019, p. 28)

The Office of Community Development began referring to the Tribal Council as "stakeholders" rather than partners. They imposed a more conventional top-down, rather than tribal-driven or participatory, planning process beginning with a needs assessment predominantly based on land-use data collection on the Island and outreach with individual households who remained on the Island rather than the collective needs of the Tribe as a community (LDOA 2017b). Tribal leaders began to question the state's commitment to their efforts and read their actions as divisively exacerbating tensions on and around the Island—what some Tribal citizens referred to as a process of "divide and conquer." Moreover, instead of relying on the existing efforts of the Tribal Council whose planning and outreach was critical to the state being awarded the NDRC award, they slowly began to roll out new leadership structures to govern the planning process, such as a project steering committee, composed of indigenous and nonindigenous Island residents, representatives from both the Isle de Jean Charles Biloxi-Chitimacha-Choctaw and United Houma Nation, and state employees to give input in the planning process (LDOA 2019a). The steering committee met six times over a 9-month period in 2018 (LDOA 2019a). The meetings then stopped abruptly confusing at least some steering committee members who began to hear about resettlement activities in the press rather than directly from the state planners themselves (Jessee Forthcoming).

State planners and their subcontractors have also rendered the extensive work of the Isle de Jean Charles Biloxi-Chitimacha-Choctaw Tribal Council has devoted to the process invisible in planning materials and public statements. From after the award announcement in 2016 until at least late 2018, the state's resettlement website displayed a project timeline with no reference to any pre-NDRC resettlement work that the Tribe had conducted or their extensive contributions to the successful NDRC application (LDOA 2018a). Timelines posted at public community planning meetings also omitted the tribal-driven history of resettlement planning (Jessee Forthcoming). Additionally, in one article written for an online planning publication, Louisiana's Resilience Policy and Program Administrator makes no mention of the Tribe's name or the indigenous heritage of the Island (Sanders 2018). Instead, he referred to the people of the Island as "pioneers" - an odd phrase to describe Native Americans given the historical role of European and American pioneers in the occupation and dispossession of indigenous peoples' lands. The article, entitled Don't Label Them Climate Change Refugees, says a Louisiana Planner, They're Pioneers, importantly rejects the paternalistic and problematic "climate refugee" discourse explicitly. It does so, however, while reproducing an ahistorical reframing of the resettlement that erases the indigenous heritage of the Island and the Tribal leaders who have advanced resettlement as a way of saving the Island's heritage. According to the article, "Many of the Island's residents are leaning in by collaborating with a project team of state officials, planners, engineers and architects to plan the look, feel, function and composition of the new community." However, 
it was Louisiana state planners who "leaned in" to collaborate with an existing Tribal Council who established and maintained a set of existing partnerships that produced clear plans for a tribal community resettlement - which was funded.

In early 2019, 3 years after tribal leaders began to feel excluded from the state's planning process - and nearly 3 years after Chief Naquin initially suspected the state was trying to transform their tribal resettlement into a subdivision- the State announced an action plan amendment to the US Department of Housing and Urban Development for a "project narrative clarification" and "introduction of new activities," formalizing a shift that began almost immediately following the award announcement. The proposed amendment replaces the section of the funded NDRC application that commits to "supporting and enhancing tribal identity, sovereignty, and dignity" and the tribal community center (LDOA 2019b). Despite their stated goal to "create an opportunity" for former residents to join the resettlement, the state's outreach has been focused predominantly on current Island residents, and only as of early 2019 did they begin to publicize the basic terms under which former Island residents can claim a spot in the new location. According to the proposed amendment, eligibility of former Island residents to claim a plot of land in the resettlement location would be restricted to those who currently own a home and "can demonstrate the financial ability to build a new home" (LDOA 2019b). The state's program amendment would enable anyone "who lived in a Hurricane Isaac federally-declared disaster parish on Aug. 28, 2012" to receive a lot in the new location and would allow the state to publicly auction lots that do not get claimed by former island residents (LDOA 2019a, p. 10). Additionally, there remain questions as to how those who could not afford to relocate on their own will afford the new costs of owning and maintaining a home, insurance, taxes, utilities, etc. given the parameters established by the Office of Community Development. Three years after the award, there is immense uncertainty as to how one of the primary goals of the Tribal leadership over the years of resettlement efforts-to reunite scattered Tribal citizens in order to ensure the Island's traditional cultural survival and growth—will be achieved.

The redefinition of the scope of the resettlement and lack of commitment to the existing tribal vision has estranged Tribal leadership from the planning process and limited the potential resources for the resettlement garnered through their advocacy. The NDRC was one of many mechanisms Tribal leaders hoped would support their long sought-after resettlement goals. In addition to working with the state's Office of Community Development toward the NDRC funding, Tribal leaders and their resettlement team secured planning support from multiple programs including the Citizens Institute for Rural Design, the Environmental Protection Agency's Healthy Places for Healthy People, the Smithsonian's Recovering Voices grant, and the National Academy of Sciences to enhance the planning process, directed toward ensuring a number of plan elements including a health clinic, honoring traditional ecological knowledge, and building their organizational capacity after years of struggling with the strains of displacement. Tribal leaders remain uncertain as to whether or not the outcomes of these efforts will be realized, because the state of Louisiana has retained ownership over the land they purchased with NDRC funds 
for the resettlement and have not committed to the incorporation of these other Tribal-driven initiatives on that land. Moreover, while the Tribe envisioned owning and governing communal spaces of the resettlement site, the recent proposed amendment states that infrastructure and recreational spaces will be "maintained by a governing nonprofit or unit of local government" (LDOA 2019b, p. 10), exacerbating questions as to how the Isle de Jean Charles Biloxi-ChitimachaChoctaw Tribe as a distinct community might plan for their future on the lands purchased for their relocation with a grant they contributed extensively to garnering. One tribal member summed up these concerns during an informal interview after hearing in the newspaper about a state planning meeting to be held the next day, despite their serving on the state-created project steering committee:

\footnotetext{
"This ain't no Road Home Program. We wanted them to help us, not take over the whole thing. My spirit aches knowing they are going to try to get people to sign up for a spot in their resettlement, while not explaining what they will have to pay since the Tribe is getting pushed out. It ain't free. We don't know what they tell people when they talk on their porches. We don't know if the people hear from the state that they will need to pay taxes or flood insurance on this new house, and it will be more than they pay now on the Island. My spirit aches because the whole tribe and tribal leaders were not invited to their meetings, and the state people do not trust us. We don't know if we should even advise our people. This was for our children. We want what is best for the future of our people as a whole. But now we are stuck between a rock and a hard place of not doing anything... But who's going to be there after 2022 when this grant ends?"
}

The state's approach to administering NDRC funds has produced immense uncertainty and threatened to alienate and undercut some of the most compelling advocates for the Island people-who also happen to be arguably the most effective advocates for coastal resettlement in Louisiana for nearly two decades. What does that do for future coastal planning? What will other community and tribal leaders learn when they reflect on how this process has unfolded? Will they have to choose between adaptation and identity? Between relocating out of harm's way and maintaining their collective self-determination? Or between safety from coastal flooding and justice? At the time of this writing, Isle de Jean Charles BiloxiChitimacha-Choctaw Tribal leaders are concerned that public perception will be they have benefitted from the $\$ 48$ million investment in their resettlement and therefore do not need continued or future support. In reality, the state's process has been incredibly painful for tribal leaders and has led to new kinds of uncertainty for the Tribe's future.

Scholars and journalists are beginning to raise questions as to the ability of public-philanthropic-sponsored design competitions to grapple with the social and historical complexities amplified by disasters and climate change. While competitions may offer resources for some jurisdictions but do not support others, they run the risk of creating divisions rather than solidarity among communities struggling to adapt (Spanne 2016). I hope that this section has highlighted that the concerns, plans, and visions advanced by tribal leaders or activists embraced by government agencies in design stages of these competitions may not transfer throughout implementation. First, the state's ambiguous approach to community-articulating both 
geographic notions inherited from the CPRA plan and risk reduction conventions that highlight physical exposure to hazards as well as tribal notions of community inherited from existing Isle de Jean Charles resettlement efforts-throughout their application and implementation processes along with regional politics have derailed the commitment of state actors to some of the most important social and cultural aspects of the initial application. Additionally, the innovation of resilience design competitions seems primarily focused on design with minimal attention to the innovations needed in governance. Local jurisdictions may draw on conventional approaches to spending federal dollars, constraining the innovation harnessed during the development of applications to those competitions. Design is not a replacement for governance, and the problems raised in this chapter should demand government agencies find new ways to support the initiatives of those already working to support community-oriented and indigenous resilience. I often wonder how things would be different today, with regard to the Isle de Jean Charles resettlement, if state policy-makers and planners had remained committed to the values and ideas embraced in initial application and their initial partnerships when they realized the social complexity of the Island, even if it meant pursuing additional funding and developing additional partnerships to accommodate other tribes and those whose visions of the future departed from the one long-advanced by the Isle de Jean Charles Biloxi-Chitimacha-Choctaw Tribe?

\subsection{Beyond Beneficiaries: Resourcing Community and Tribal-Driven Resettlements}

Given the historical and contemporary tensions described in previous sections of this chapter, policy-makers, planners, and funders should concentrate on adjusting planning conventions, grant implementation processes, federal regulations, and expectations in order to engage in participatory processes that ensure community leaders — or in the case of tribal resettlement, tribal leadership_remain in control of their complex and dynamic adaptation processes. What should the Tribe have been told about their rights to maintain ownership over the resettlement ideas that they had been honing for about 20 years when they shared them with the state, thinking the state was going to support their existing efforts to lead their resettlement? What role should the state have taken to support those tribal leaders already mobilizing to resettle their communities en groupe? Once tensions between notions of community and goals for resettlement emerged, what would have been a better process for harmonizing divergent adaptation aims?

One resource for policy-makers, scholars, and practitioners engaged with those already working on resettlement planning processes is The Peninsula Principles on Climate Displacement Within States - a policy document produced by Displacement Solutions in 2013 based on consultation with international experts in human rights, international law, refugees, and migration. The principles highlight the agency and 
dignity of those experiencing displacement and frame the role of state agencies as resource providers and advocates more so than leaders of resettlement processes. According to the principles, national policies should institutionalize the government's role as providers of resources, assistance, and protection against human rights abuses. Mackinnon and Derickson (2013) 's "politics of resourcefulness" is also useful. Their work highlights the need to distribute resources with the goal of addressing inequalities, to institutionalize and commit to democratic and participatory processes and capacity building within communities, to value traditional indigenous knowledges (ecological and other forms of expertise), and to ensure the political and cultural recognition of communities and tribes. As indicated earlier in the chapter, the United Nations Declaration on the Rights of Indigenous Peoples is also a critical resource.

There is also a need for planners and policy-makers to enhance organizing capacity when it is not fully developed. Though many community and tribal leaders, like the Isle de Jean Charles Biloxi-Chitimacha-Choctaw Tribal Council, have long begun planning their resettlements to ensure a future for their people in the wake of climate-related hazards and disaster, they likely also need various kinds of support to fully realize their visions and in dealing with the effects of existing displacement. Government representatives have access to many resources that might be useful to resettling communities including knowledge of agencies, laws, and procedures; people to serve as staff; letters of support; and grant writing skills. State or federal agencies could also provide financial compensation for time spent on resettlement activities, office space for community or tribal use, and guidance for people to gather additional resources themselves. Providing material support to existing community-to-community and tribe-to-tribe knowledge exchanges and to existing relationships of solidarity among community-based organizations would enhance resilience and might also supplement governmental deficiencies (Lazrus et al. 2016; Maldonado et al. 2015). Access to professional networks, like the American Planning Association, the Society for Applied Anthropology, Rising Voices, and the Rural Sociological Society, are also potentially valuable.

Outcomes of any knowledge-generating processes related to resilience or resettlement planning are hot commodities at the moment. There is widespread demand for publications of "best practices" or "lessons learned" of resilience and adaptation processes. Indeed, one of the goals of governmental support for the Isle de Jean Charles Biloxi-Chitimacha-Choctaw resettlement was to develop a conduit for future learning about resettlement processes and sustainable development. The Tribal leadership and their team of partners had embraced that role using their resettlement to create a teaching and learning community for sustainable development. The state of Louisiana has indicated they envision a resettlement process which is a "scalable" and "replicable" model (LDOA 2018b). Louisiana state planners have presented their work on this resettlement at numerous conferences including the American Planning Association, American Association of Geographers, and others around the world without including Tribal leaders and their knowledge of the long road to resettlement. For more just processes of resettlement knowledge sharing, it is critical that local activists and Tribe-based partners have real power and 
authorship in the activities through which their experiences, struggles, and activism are represented, objectified, commodified, and circulated for multi-societal benefit. These kinds of presentations and any reports produced should be crafted in collaboration and co-authored with community-based organizations and Tribal leaders, and the resources acquired from the circulation of documented outcomes should directly benefit those community-based organizations monetarily and through recognition. This is especially important during Tribal resettlements, where intellectual property issues and representations of identity, ancestry, and social organization are so often conditioned by historical colonial social relations and can be used to threaten cultural survival or political recognition.

\subsection{Conclusions}

In this chapter I have argued that historical atrocities and intergenerational experiences of injustice influence the lived experiences of contemporary adaptation policy and resettlement planning efforts. The refusal of risk reduction professionals to adequately address past injustices and their social and environmental legacieswhat I refer to as ahistorical adaptation-can disrupt efforts to build meaningful partnerships between communities or tribes and government agencies. A lack of awareness and explicit acknowledgment of local and national histories of race and racism, the politics of disaster, or struggles for self-determination, for example, might be felt as an invalidation of peoples' experiences, suffering, perseverance, and wisdom. Without meaningfully addressing broader social, cultural, and historical contexts, climate change adaptation policies may serve as just another site for the continued oppression of already marginalization peoples.

In order to avoid ahistorical adaptation, I call on risk reduction professionals, state planners, scholars (myself included), and others engaged in hazard mitigation and environmental adaptation — especially community resettlement processes- to conceptualize and conduct their work through wider timelines and notions of risk and adaptation than they may be accustomed. Many of the state planners I have spoken with during the course of my research who are working on administering National Disaster Resilience Competition funds for the Isle de Jean Charles resettlement acknowledge the histories discussed in this chapter and their legacies within individual conversations. Also, the final LA SAFE regional adaptation strategy, which was released as this chapter was headed to press, briefly acknowledges the legacies of colonialism and racism and how they contribute to current risk (LDOA 2019c, p 96-97). This evolution from earlier drafts of the framework might demonstrate an increasing sensitivity to the historical production of vulnerability. Future research might explore 1) the suitability of the recommended strategies advanced in that document for addressing the scope of risks that Louisiana residents face, 2) the extent to which the strategies lead to the redress of injustices mentioned in the "Race and Ethnicity" blurb, and 3) the appropriate role of oil and gas industries in resilience and adaptation policy in Louisiana. In order to meaningfully adapt to 
the socio-ecological risks that threaten coastal habitability in Louisiana, state and federal policy-makers, scholars, planners, and others working on environmental adaptation must reckon with the entangled roots of risk: settler colonization, racism, capitalism, and the environmental destruction caused by industrial development. Inequalities and violence related to gender and sexuality should also be considered in this context though it is regrettably missing from the analysis in this chapter.

Policy and planning approaches must provide adequate resources for the implementation of community-based and tribal-driven adaptation initiatives, especially when, as in the case of the Isle de Jean Charles Biloxi-Chitimacha-Choctaw Tribe, those efforts have been underway for nearly two decades. Resilience and adaptation policies and practice should bolster existing environmental and social justice efforts by finding ways to provide financial and other needed resources to those doing this essential work. Tribal and community resettlement processes evoke disparate legal and policy worlds that relate to grant administration, property law, and the rights of indigenous peoples_-making public support for just resettlement processes incredibly complex and potentially impossible without significant social, cultural, legal, and bureaucratic transformation. Institutionalizing the kinds of support most needed will likely require changes in federal and state regulations, budgets, and more serious conversations about holding extractive industries accountable. Providing reparations for legacies of forced displacement, slavery, land grabs, and impacts of deforestation and oil and gas development should be investigated as resilience and adaptation strategies. While the focus of risk reduction professionals and policymakers may remain transfixed on the future-imagining new relationships to place and habitation in flood zones-we must simultaneously reckon with the past. "Reshaping" coastal Louisiana must include reshaping the colonial social relations that have devastated this landscape and many of the people who have lived, and who currently live, here.

\section{References}

Austin, D. E. (2006). Coastal exploitation, land loss, and hurricanes: a recipe for disaster. American Anthropologist, 108(4), 671-691. https://doi.org/10.1525/aa.2006.108.4.671.

Barker, J. (2011). Native acts: Law, recognition, and cultural authenticity. Durham: Duke University Press.

Barry, J. M. (1997). Rising tide: The great Mississippi flood of 1927 and how it changed America. New York: Touchstone.

Batte, J. (2016, May 11). Tensions arise between local Indian tribes over effort to abandon sinking island. HoumaToday, Retrieved from https://www.houmatoday.com/news/20160511/ tensions-arise-between-local-indian-tribes-over-effort-to-abandon-sinking-island

Bettini, G. (2017). Unsettling futures: Climate change, migration, and the (ob)scene biopolitics of resilience. In A. Baldwin \& G. Bettini (Eds.), Life adrift: Climate change, migration, critique (pp. 79-96). Lanham: Rowman \& Littlefield Publishers.

Bronen, R. (2011). Climate-induced community relocations: Creating an adaptive governance framework based in human rights doctrine. New York University Review of Law and Social Change, 35(2), 356-406. Retrieved from https://socialchangenyu.com/. 
Bronen, R., Maldonado, J. K., Marino, E., \& Hardison, P. (2018). Climate change and displacement: Challenges and needs to address an imminent reality. In M. Cernea \& J. K. Maldonado (Eds.), Challenging the prevailing paradigm of displacement and resettlement: Risks, impoverishment, legacies, solutions (pp. 252-272). New York: Routledge.

Burkett, M., Verchick, R. R. M., \& Flores, D. (2017). Reaching higher ground: Avenues to secure and manage new land for communities displaced by climate change. Center for Progressive Reform. Washington, DC: Center for Progressive Reform. Retrieved from http://progressivereform.org/articles/ReachingHigherGround_1703.pdf

Carter, L., Terando, A., Dow, K., Hiers, K., Kunkel, K. E., Lascurain, A., et al. (2018). In D. R. Reidmiller, C. W. Avery, D. R. Easterling, K. E. Kunkel, K. L. M. Lewis, T. K. Maycock, $\&$ B. C. Stewart (Eds.), Impacts, risks, and adaptation in the United States: Fourth national climate assessment (Vol. II, pp. 743-808). Washington, DC: U.S. Global Change Research Program.

Cernea, M. M. (1997). The risks and reconstruction model for resettling displaced populations. World Development, 25(10), 1569-1587. https://doi.org/10.1016/S0305-750X(97)00054-5.

Cernea, M. M. (2000). Risks, safeguards, and reconstruction: A model for population displacement and resettlement. In M. Cernea \& C. McDowell (Eds.), Risks and reconstruction: Experiences of resettlers and refugees (pp. 11-15). Washington, DC: The World Bank.

Clipp, A., Gentile, B., Green, M., Galinski, A., Harlan, R., Rosen, Z., et al. (2017). 2017 Coastal Master Plan: Appendix B: People and the landscape. Version Final. (43 pp.). Baton Rouge: Coastal Protection and Restoration Authority. Retrieved from http://coastal.la.gov/wp-content/ uploads/2017/04/Appendix-B_People-and-the-Landscape_FINAL.pdf

Coastal Protection and Restoration Authority (CPRA). (2017). 2017 Coastal master plan: Appendix E: Flood risk and resilience program framework. Version Final. (pp. 1-66). Baton Rouge: Coastal Protection and Restoration Authority. Retrieved from http://coastal.la.gov/wpcontent/uploads/2016/04/Appendix-E_FINAL_10.09.2017.pdf

Cohen, F. S. (2005). Cohen's handbook of federal Indian law. Newark: LexisNexis.

Collier, S. J., Cox, S., \& Grove, K. (2016). Rebuilding by design in post-Sandy NYC. LIMN, 7. Retrieved from https://limn.it/rebuilding-by-design-in-post-sandy-new-york/

Colten, C. E. (2017). Environmental management in coastal Louisiana: A historical review. Journal of Coastal Research, 33(3), 699-711. https://doi.org/10.2112/JCOASTRES-D-16-00008.1.

Colten, C. E., Simms, J. R., Grismore, A. A., \& Hemmerling, S. A. (2018). Social justice and mobility in coastal Louisiana, USA. Regional Environmental Change, 18(2), 371-383. https:// doi.org/10.1007/s10113-017-1115-7.

Comstock, D., \& Fox, R. (1993). Participatory research as critical theory: The North Bonneville, USA, experience. In P. Park, M. Brydon-Miller, B. Hall, \& T. Jackson (Eds.), Voices of change: Participatory research in the United States and Canada (pp. 103-124). Westport: Bergin \& Garvey.

Couvillion, B. R., Beck, H., Schoolmaster, D., \& Fischer, M. (2017). Land area change in coastal Louisiana (1932 to 2016) (No. 3381). Reston: US Geological Survey. https://doi.org/10.3133/ $\operatorname{sim} 3381$.

Crepelle, A. (2019). The United States first climate relocation: recognition, relocation, and indigenous rights at the Isle de Jean Charles. Belmont Law Review, 6, 1), 1-1),40. Retrieved from http://www.belmont.edu/law/.

Cronin, V., \& Guthrie, P. (2011). Community-led resettlement: From a flood-affected slum to a new society in Pune, India. Environmental Hazards, 10(3-4), 310-326. https://doi.org/10.108 0/17477891.2011.594495.

Crowell, M., Coulton, K., Johnson, C., Westcott, J., Bellomo, D., Edelman, S., et al. (2010). An estimate of the U.S. population living in 100-year coastal flood hazard areas. Journal of Coastal Research, 26(2), 201-211. https://doi.org/10.2112/jcoastres-d-09-00076.1.

Cusik, D., \& Aton, A. (2017). Puerto Ricans could be newest U.S. climate refugees. Scientific American E \& E News: Climate. Retrieved from https://www.scientificamerican.com/ author/e-e-news/ 
Dalbom, C., Hemmerling, S. A., \& Lewis, J. (2014). Community resettlement prospects in Southeast Louisiana: A multidisciplinary exploration of legal, cultural, and demographic aspects of moving individuals and communities. New Orleans: Tulane Institute on Water Resources Law \& Policy. Retrieved from http://www.law.tulane.edu/uploadedFiles/Institutes_and_Centers/ Water_Resources_Law_and_policy/Content/Community\%20Resettlement\%20Prospects $\% 20$ in $\% 20$ Southeast $\% 20$ Louisana.pdf

Dawson, A. (2017). Extreme Cities: The peril and promise of urban life in the age of climate change. London: Verso.

Den Ouden, A. E., \& O'Brien, J. M. (Eds.). (2013). Recognition, sovereignty struggles, and indigenous rights in the United States: A sourcebook. Chapel Hill: UNC Press Books.

Dunbar-Ortiz, R. (2014). An Indigenous Peoples' history of the United States. Boston: Beacon Press.

Estes, N. (2019). Our History Is the Future: Standing Rock Versus the Dakota Access Pipeline, and the Long Tradition of Indigenous Resistance. New York City: Verso Books.

Faas, A. J. (2016). Disaster vulnerability in anthropological perspective. Annals of Anthropological Practice, 40(1), 14-27. https://doi.org/10.1111/napa.12084.

Ferguson-Bohnee, P. (2018, May). Self determination in a sinking basin - hurdles and hindrances to protecting tribal cultural heritage in Southern Louisiana. Presentation at the State of the Coast Conference. New Orleans, LA.

Ferris, E. (2012). Protection and planned relocations in the context of climate change. Geneva: UN High Commission of Refugees, Division of International Protection. Retrieved from http:// www.unhcr.org/5024d5169.html

Fleming, B. (2019). Design and the Green New Deal. Places Journal, Retrieved from https://placesjournal.org/article/design-and-the-green-new-deal

Fullilove, M. T. (2005). Root shock: How tearing up city neighborhoods hurts Americans and what we can do about it. New York: One World Press.

Gohd, C. (2018, January 5). A wave of climate refugees could soon emerge in the US. Futurism. Retrieved from https://futurism.com/wave-climate-refugees-soon-emerge-us/

Hardy, R. D., Milligan, R. A., \& Heynen, N. (2017). Racial coastal formation: The environmental injustice of colorblind adaptation planning for sea-level rise. Geoforum, 87, 62-72. https://doi. org/10.1016/j.geoforum.2017.10.005.

Hardy, D., Lazrus, H., Mendez, M., Orlove, B., Rivera-Collazo, I., Roberts, et al. (2018). Social vulnerability: Social science perspectives on climate change, Part 1. Washington, DC: USGCRP Social Science Coordinating Committee. Retrieved from https://www.globalchange. gov/content/social-science-perspectives-climate-change-workshop

Hauer, M. E., Evans, J. M., \& Mishra, D. R. (2016). Millions projected to be at risk from sea level rise in the continental United States. Nature Climate Change, 6, 691-694. https://doi. org/10.1038/nclimate2961.

Hobor, G., Plyer, A., \& Horwitz, B. (2014). The coastal index. New Orleans: The Data Center. Retrieved from https://s3.amazonaws.com/gnocdc/reports/TheDataCenter_TheCoastalIndex. pdf.

Jankowski, K. L., Törnqvist, T. E., \& Fernandes, A. M. (2017). Vulnerability of Louisiana's coastal wetlands to present-day rates of relative sea-level rise. Nature Communications, 8, 14792. https://doi.org/10.1038/ncomms14792.

Jerolleman, A. (2019). Disaster recovery through the lens of justice. Springer Nature.

Jessee, N. (2015). Can't Stop the Water Jason Ferris and Rebecca Marshall Ferris, dirs. 40 min. Philadelphia: Cottage Films, 2013. American Anthropologist, 117(4), 808-810. https://doi. org/10.1111/aman.12376.

Jessee, N. (2016, April 22). Hope for "just resilience" on Earth Day. EnviroSociety. Retrieved from www.envirosociety.org/2016/04/hope-for-just-resilience-on-earth-day

Jessee, N. (Forthcoming). Reshaping Louisiana's Coastal Frontier (Unpublished doctoral dissertation). Temple University. 
Katz, M. (2003). Staying afloat: How federal recognition as a Native American tribe will save the residents of Isle de Jean Charles, Louisiana. Loyola Journal of Public Interest Law, 4(1), 126. Retrieved from http://law.loyno.edu/loyola-journal-public-interest-law.

Keene, E. (2017). Lessons from relocations past: Climate change, tribes, and the need for pragmatism in community relocation planning. American Indian Law Review, 42(1), 259. https://www. jstor.org/stable/10.2307/26492279.

Koenig, K. A., \& Stein, J. (2013). State recognition of American Indian Tribes: A survey of staterecognized tribes and state recognition processes. In A. E. Den Ouden \& J. M. O’Brien (Eds.), Recognition, sovereignty struggles, and indigenous rights in the United States: A sourcebook (pp. 115-148). Chapel Hill: UNC Press Books.

Koslov, L. (2016). The case for retreat. Public Culture, 28(2), 359-387. https://doi. org/10.1215/08992363-3427487.

Kuh, K. F. (2016). Agnostic adaptation. In R. K. Craig \& S. R. Miller (Eds.), Contemporary issues in climate change law and policy: Essays inspired by the IPCC (pp. 167-180). Washington, DC: ELI Press.

Louisiana Office of Indian Affairs (LA Indian Affairs). (2018). Federal and State Tribal Contact List - 2018. Baton Rouge: Louisiana Office of Indian Affairs. Retrieved from http://gov.louisiana.gov/assets/Programs/IndianAffairs/LouisianaTribes.pdf

Laska, S., Peterson, K., Alcina, M. E., West, J., Volion, A., Tranchina, B., et al. (2010). Enhancing Gulf of Mexico coastal communities' resiliency through participatory community engagement. CHART Publications. Paper 21. New Orleans: UNO-CHART. Retrieved from https://scholarworks.uno.edu/chart_pubs/2

Laska, S., Peterson, K., Rodrigue, C., Cosse', T., Philippe, R., Burchett, O., et al. (2015). "Layering" of natural and human caused disasters in the context of anticipated climate change disasters: The coastal Louisiana experience. In M. Companion (Ed.), The impact of disasters on livelihoods and cultural survival: Opportunities, losses and mitigation (pp. 225-238). Boca Raton: CRC Press.

Lasley, C. B. (2012). Catastrophes and the role of social networks in recovery: A case study of St. Bernard Parish, LA, residents after Hurricane Katrina (dissertation). New Orleans: University of New Orleans Theses and Dissertations. (1504).

Lazrus, H., Gough, B., \& Maldonado, J. (2016). The rising voices: Building bridges between scientific and indigenous communities. Natural Hazards Observer, 40(4), 16-20. Retrieved from https://hazards.colorado.edu/natural-hazards-observer/volume-xl-number-8.

Lindemuth, J. (2017). Re: Legal status of tribal governments in Alaska. Anchorage: Department of Law, Office of Attorney General. Retrieved from https://s3.amazonaws.com/arc-wordpress-client-uploads/adn/wp-content/uploads/2017/10/21021026/AG-Opinion-re-Tribal-Governmentin-Alaska.pdf

Logan, J. R., Zhang, W., \& Alba, R. D. (2002). Immigrant enclaves and ethnic communities in New York and Los Angeles. American Sociological Review, 67(2), 299-322. https://doi. org/10.2307/3088897.

Louisiana Act 102 House Bill 660 (2018).

Louisiana Budget Project. (2018, September 13). Poverty and income inequality continue to plague Louisiana. Louisiana Budget Project. Retrieved from http://www.labudget.org/2018/09/ release-povertyand-incomeinequality-continue-to-plague-louisiana/

Louisiana Department of Administration (LDOA). (2015a). Resettlement as a resilience strategy and the case of Isle de Jean Charles. Office of Community Development Disaster Recovery Unit (OCD DRU). Baton Rouge: OCD DRU. Retrieved from http://www.doa.la.gov/ocddru/ ndrc/idjc_prospectus_final_27oct15_updated_logos.pdf

Louisiana Department of Administration (LDOA). (2015b). National Disaster Resilience Competition Phase II Application. Baton Rouge: Louisiana Department of Administration.

Louisiana Department of Administration (LDOA). (2015c). National Disaster Resilience Competition Phase II Application, Attachment D: Consultation Summary Public Comment Summary \& Responses. Office of Community Development Disaster Recovery Unit (OCD 
DRU). Baton Rouge: OCD DRU. Retrieved from https://www.doa.la.gov/OCDDRU/NDRC/ AttchD_ConsultationSummary_LA.pdf

Louisiana Department of Administration (LDOA). (2017a). LA SAFE Louisiana's strategic adaptations for future environments policy framework. Baton Rouge: Louisiana Department of Administration. Retrieved from https://www.doa.la.gov/ocddru/ndrc/lasafe_Report_Final.pdf

Louisiana Department of Administration (LDOA). (2017b). The Resettlement of Isle de Jean Charles: Report on data gathering and engagement phase. Baton Rouge: Louisiana Department of Administration. Retrieved from http://isledejeancharles.la.gov/sites/default/files/public/ IDJC-Final-Report-Update.pdf

Louisiana Department of Administration (LDOA). (2018a). Isle de Jean Charles project timeline. Baton Rouge: Louisiana Department of Administration. Retrieved from http://isledejeancharles.la.gov

Louisiana Department of Administration (LDOA). (2018b). A message from Pat Forbes, Executive Director of OCD. Baton Rouge: Louisiana Department of Administration. Retrieved from http://isledejeancharles.la.gov

Louisiana Department of Administration (LDOA). (2019a). Resettlement of Isle de Jean Charles-Background and overview. Baton Rouge: Louisiana Department of Administration. Retrieved from http://isledejeancharles.la.gov/sites/default/files/public/ IDJC_Background_Overview_3_20_19

Louisiana Department of Administration (LDOA). (2019b). Substantial Amendment 5: Introduction of new activities and project narrative clarifications for the utilization of community development block grant funds under the National Disaster Resilience Competition (NDRC) Resettlement of Isle de Jean Charles. Baton Rouge: Louisiana Department of Administration. Retrieved from https://www.doa.la.gov/OCDDRU/Action\%20Plan\%20Amendments/NDR/ IDJC_Substantial_APA_5_FINAL03272019.pdf

Louisiana Department of Administration (LDOA). (2019c). Our land and water: A regional approach to adaptation. Baton Rouge: Louisiana Department of Administration. Retrieved from https://s3.amazonaws.com/lasafe/Final+Adaptation+Strategies/ Regional+Adaptation+Strategy.pdf

Louisiana Housing Corporation. (2019). Louisiana housing needs assessment. Public Administration Institute E.J. Louisiana State University. Baton Rouge, LA. Retrieved from https://www.lhc.la.gov/hubfs/Document\%20Libraries/Housing\%20Policy\%20and\%20Data/ RLMA3.pdf

Louisiana Senate Concurrent Resolution 105. (2004). Louisiana State Senate, Baton, Rouge, LA.

MacKinnon, D., \& Derickson, K. D. (2013). From resilience to resourcefulness: A critique of resilience policy and activism. Progress in Human Geography, 37(2), 253-270. https://doi. org/10.1177/0309132512454775.

Macklin, R. (2009). Eliminating health disparities: From a grass-roots perspective. Bureau of Minority Health Access. Retrieved from http://ldh.la.gov/assets/docs/GovCouncil/MinHealth/ HealthDisparitiesReport200809.pdf

Maldonado, J. K. (2014). A multiple knowledge approach for adaptation to environmental change: Lessons learned from coastal Louisiana's tribal communities. Journal of Political Ecology, 21, 61-82. https://doi.org/10.2458/v21i1.21125.

Maldonado, J. K. (2018). Seeking justice in an energy sacrifice zone: Standing on vanishing land in coastal Louisiana. New York: Routledge.

Maldonado, J. K., Shearer, C., Bronen, R., Peterson, K., \& Lazrus, H. (2013). The impact of climate change on tribal communities in the US: Displacement, relocation, and human rights. Climatic Change, 120(3), 601-614. https://doi.org/10.1007/s10584-013-0746-z.

Maldonado, J. K., Naquin, A. P., Dardar, T., Parfait-Dardar, S., \& Bagwell, B. (2015). Above the rising tide: Coastal Louisiana's tribal communities apply local strategies and knowledge to adapt to rapid environmental change. In M. Companion (Ed.), Disasters' impact on livelihood and cultural survival: Losses, opportunities, and mitigation (pp. 239-253). Boca Raton: CRC Press. 
Manning-Broome, C., Dubinin, J., \& Jenkins, P. (2015). View from the Coast: Local perspectives and policy recommendations on flood-risk reduction in south Louisiana. [Policy report]. Baton Rouge: Center for Planning Excellence.

Marino, E. (2012). The long history of environmental migration: Assessing vulnerability construction and obstacles to successful relocation in Shishmaref, Alaska. Global Environmental Change, 22(2), 374-381. https://doi.org/10.1016/j.gloenvcha.2011.09.016.

Marino, E. (2015). Fierce climate, sacred ground: An ethnography of climate change in Shishmaref, Alaska. Fairbanks: University of Alaska Press.

Matz, D., Vogel, E. B., Mattar, S., \& Montenegro, H. (2015). Interrupting intergenerational trauma: Children of Holocaust survivors and the Third Reich. Journal of Phenomenological Psychology, 46(2), 185-205. https://doi.org/10.1163/15691624-12341295.

McCintire, W. G. (1954). Prehistoric settlements of coastal Louisiana (dissertation). Baton Rouge: Louisiana State University Historical Dissertations and Theses. (8099).

Miller, M. (2004). Forgotten tribes: Unrecognized Indians and the federal acknowledgment process. Lincoln: University of Nebraska Press.

Nagata, D. K., Kim, J. H. H., \& Nguyen, T. U. (2015). Processing cultural trauma: Intergenerational effects of the Japanese American Incarceration. Journal of Social Issues, 71(2), 56-370. https:// doi.org/10.1111/josi.12115.

Nelson, M., Ehrenfeucht, R., \& Laska, S. (2007). Planning, plans, and people: Professional expertise, local knowledge, and governmental action in post-hurricane Katrina New Orleans. Cityscape, 9(3), 23-52. https://www.jstor.org/stable/20868630.

O'Keefe, P., Westgate, K., \& Wisner, B. (1976). Taking the naturalness out of natural disasters. Nature, 260, 566-567. https://doi.org/10.1038/260566a0.

Oliver-Smith, A. (2009). Development and dispossession: The crisis of forced displacement and resettlement. Santa Fe: School for Advanced Research Press.

Oliver-Smith, A., \& Hoffman, S. (1999). The angry earth: Disaster in anthropological perspective. New York: Routledge.

Perry, R. W., \& Lindell, M. K. (1997). Principles for managing community relocation as a hazard mitigation measure. Journal of Contingencies and Crisis Management, 5(1), 49-59. https://doi. org/10.1111/1468-5973.00036.

Peterson, K., \& Maldonado, J. K. (2016). When adaptation is not enough: Between the "now and then" of community-led resettlement. In S. A. Crate \& M. Nuttall (Eds.), Anthropology and climate change: From action to transformation (2nd ed.). New York: Routledge.

Randolph, N. (2018). License to extract: How Louisiana's Master Plan for a Sustainable Coast is sinking it. Lateral- Journal of the Cultural Studies Association, 7(2). https://doi.org/10.25158/ L7.2.8.

Rigaud, K. K., Jones, B., Bergmann, J., Clement, V., Ober, K., Schewe, J., et al. (2018). Groundswell: Preparing for internal climate migration. Washington, DC: World Bank.

Rivard, C. (2015). Archival recognition: The Pointe-au-Chien's and Isle de Jean Charles Band of the Biloxi-Chitimacha Confederation of Muskogees' fight for federal recognition. Settler Colonial Studies, 5(2), 117-127. https://doi.org/10.1080/2201473X.2014.957257.

Sanders, M. (2018, August 23). Don't label them climate change refugees, says a Louisiana planner, they're pioneers. Common Edge. Retrieved from http://commonedge.org/ dont-labelthem-climate-change-refugees-says-a-louisiana-planner-theyre-pioneers/

Sassaman, K. E., \& Anderson, D. (2004). Late Holocene Period, 3750 to 650 B.C. In R. D. Fogelson (Ed.), The handbook of North American Indians. Vol. 14, Southeast (pp. 101-114). Washington, DC: Smithsonian Institution Press.

Simms, J. R. (2016). "Why would I live anyplace else?": Resilience, sense of place, and possibilities of migration in coastal Louisiana. Journal of Coastal Research, 33(2), 408-420. https:// doi.org/10.2112/jcoastres-d-15-00193.1.

Simon, D. (2008, 22 September). Tribal chief on Isle de Jean Charles says it's time to leave. Nola. com. Retrieved from https://www.nola.com/news/2008/09/tribal_chief_on_isle_de_jean_c. html 
Sneath, S. (2018, July 26). Louisiana tribes say federal recognition will help to face threat of climate change. The Times-Picayune. Retrieved from https://www.nola.com/expo/news/ err2018/07/449c2f22d39490/louisiana-tribes-say-federalr.html

Solet, K. (2006). Thirty years of change: How subdivisions on stilts have altered a Southeast Louisiana Parish's coast, landscape and people (dissertation). New Orleans: University of New Orleans Theses and Dissertations. (1029).

Spanne, A. (2016, March 23). The lucky ones: Native American tribe receives $\$ 48 \mathrm{~m}$ to flee climate change. The Guardian. Retrieved from https://www.theguardian.com/environment/2016/ mar/23/native-american-tribes-first-nations-climate-change-environment-indican-removal-act

Starna, W. A. (1992). "Public ethnohistory" and Native-American communities: History or administrative genocide? Radical History Review, 1992(53), 126-139. https://doi. org/10.1215/01636545-1992-53-126.

Swyngedouw, E. (2011). Depoliticized environments: the end of nature, climate change and the post-political condition. Royal Institute of Philosophy Supplements, 69, 253-274. https://doi. org/10.1017/S1358246111000300.

The Peninsula Principles on Climate Displacement within States. Displacement solutions. (2013). Geneva. Retrieved from http://displacementsolutions.org/wp-content/uploads/final-peninsulaPrinciples final.pdf

Tierney, K. (2014). The social roots of risk: producing disasters, promoting resilience. Stanford: Stanford Business Books, an imprint of Stanford University Press.

Titz, A., Cannon, T., \& Krüger, F. (2018). Uncovering "community": Challenging an elusive concept in development and disaster related work. Societies, 8, 71. https://doi.org/10.3390/ soc8030071.

Tuck, E., \& Yang, K. W. (2012). Decolonization is not a metaphor. Decolonization: Indigeneity, Education \& Society, 1(1), 1-40. Retrieved from https://www.materialculture.nl/sites/default/ files/201902/Decolonization_Is_Not_a_Metaphor.pdf.

Turner, R. E., \& McClenachan, G. (2018). Reversing wetland death from 35,000 cuts: Opportunities to restore Louisiana's dredged canals. PLoS One, 13(12). https://doi.org/10.1371/journal. pone.0207717.

U.S. Army Corps of Engineers (USACE). (2013). Revised programmatic environmental impact statement for the Morganza to the Gulf of Mexico project. Retrieved from http://www.mvn. usace.army.mil/Portals/56/docs/PD/Projects/MTG/FinalRevisedProgrammaticISMtoG.pdf

U.S. Department of Housing and Urban Development (HUD). (2015). National Disaster Resilience Competition Phase II Fact Sheet. Washington, DC: U.S. Department of Housing and Urban Development. Retrieved from https://www.hud.gov/sites/documents/ NDRCFACTSHEETFINAL.PDF

U.S. Department of Labor, Bureau of Labor Statistics. (2018). Louisiana economy at A glance. Washington, DC: U.S. Department of Labor. Retrieved from https://www.bls.gov/eag/eag. la.htm.

U.S. Geological Survey, Earth Resources Observation and Science Center. (2017). Isle de Jean.

UN General Assembly (2007). United Nations Declaration on the Rights of Indigenous Peoples. Resolution adopted by the General Assembly on 2 October 2007. A/RES/61/295. Retrieved from http://www.refworld.org/docid/471355a82.html

Walls, M. L., \& Whitbeck, L. B. (2012). The intergenerational effects of relocation policies on indigenous families. Journal of Family Issues, 33(9), 1272-1293. https://doi.org/10.1177/019 $2513 X 12447178$.

Weber, L., \& Peak, L. (2012). Displaced life in the Katrina diaspora. Austin: University of Texas Press.

Wendland, T. (2018, January 5). Lack of funds keeps Louisiana from buying out coastal residents. NPR. Retrieved from https://www.npr.org/2018/01/05/575876626/ lack-of-fundskeeps-louisiana-from-buying-out-coastal-residents 
Whyte, K. P. (2016). Is it colonial déjà vu?: Indigenous peoples and climate injustice. In J. Adamson \& M. Davis (Eds.), Humanities for the environment: Integrating knowledge, forging new constellations of practice (pp. 88-105). New York: Routledge.

Wildcat, D. R. (2009). Red alert!: Saving the planet with Indigenous knowledge. Golden: Fulcrum.

Williams, B. (2002). The concept of community. Reviews in Anthropology, 31(4), 339-350. https:// doi.org/10.1080/00988150214749.

Wilmsen, B., \& Webber, M. (2015). What can we learn from the practice of development-forced displacement and resettlement for organized resettlements in response to climate change? Geoforum, 58, 76-85. https://doi.org/10.1016/j.geoforum.2014.10.016.

Wilson, S. G., \& Fischetti, T. R. (2010). Coastline population trends in the United States: 1960 to 2008, U.S. U.S. Census Bureau Publication No. P25-1139. Washington, DC: U.S. Census Bureau. Retrieved from https://www.census.gov/prod/2010pubs/p25-1139.pdf

Wisner, B., Blaikie, P., Cannon, T., \& Davis, I. (2004). At risk: Natural hazards, people's vulnerability, and disasters (2nd ed.). London: Routledge.

Wolfe, P. (2006). Settler colonialism and the elimination of the native. Journal of Genocide Research, 8(4), 387-409. https://doi.org/10.1080/14623520601056240.

Open Access This chapter is licensed under the terms of the Creative Commons Attribution 4.0 International License (http://creativecommons.org/licenses/by/4.0/), which permits use, sharing, adaptation, distribution and reproduction in any medium or format, as long as you give appropriate credit to the original author(s) and the source, provide a link to the Creative Commons license and indicate if changes were made.

The images or other third party material in this chapter are included in the chapter's Creative Commons license, unless indicated otherwise in a credit line to the material. If material is not included in the chapter's Creative Commons license and your intended use is not permitted by statutory regulation or exceeds the permitted use, you will need to obtain permission directly from the copyright holder.

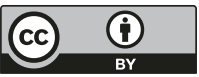

